\title{
Peripheral Deafferentation-Driven Functional Somatosensory Map Shifts Are Associated with Local, Not Large-Scale Dendritic Structural Plasticity
}

\author{
Vanessa Schubert, Daniel Lebrecht, and Anthony Holtmaat \\ Department of Basic Neurosciences, Geneva Neuroscience Center, University of Geneva, 1211 Geneva, Switzerland
}

\begin{abstract}
Long-term peripheral deafferentation induces representational map changes in the somatosensory cortex. It has been suggested that dendrites and axons structurally rearrange in such paradigms. However, the extent and process of this plasticity remains elusive. To more precisely quantify deafferentation-induced structural plasticity of excitatory cells we repeatedly imaged GFP-expressing L2/3 and L5 pyramidal dendrites in the mouse barrel cortex over months after the removal of a subset of the whisker follicles (FR), a procedure that completely and permanently removes whisker-sensory input. In the same mice we imaged whisker-evoked intrinsic optical signals (IOS) to assess functional cortical map changes. FR triggered the expansion of spared whisker IOS responses, whereas they remained unchanged over months in controls. The gross structure and orientation of apical dendrite tufts remained stable over a two-month period, both in controls and after deprivation. However, terminal branch tip dynamics were slightly reduced after FR, and the formation of new dendritic spines was increased in a cell-type and location-dependent manner. Together, our data suggest that peripheral nerve lesioninduced cortical map shifts do not depend on the large scale restructuring of dendritic arbors but are rather associated with local cell-type and position-dependent changes in dendritic synaptic connectivity.
\end{abstract}

\section{Introduction}

Long-term sensory deprivation induces representational map changes in the somatosensory cortex (Merzenich et al., 1983). This is characterized by an increase of cortical space occupied by spared sensory inputs at the expense of lost inputs. These large map shifts likely depend on changes in neuronal connectivity, mediated by the generation and loss of synapses (Holtmaat et al., 2009). The level of structural plasticity seems to depend on age of the animal, and the type and duration of the sensory deprivation. During development, dendrites and axons are highly dynamic and sensitive to changes in experience (Kossut and Juliano, 1999; Lendvai et al., 2000; Majewska and Sur, 2003; Dubroff et al., 2005; Bruno et al., 2009; Wimmer et al., 2010). However, this plasticity strongly decreases in adulthood (Maravall et al., 2004; PorteraCailliau et al., 2005; De Paola et al., 2006; Lee et al., 2006). In the adult, a mild and transient reduction of sensory input (e.g., closure of an eye, or trimming of a whisker) usually causes changes

\footnotetext{
Received March 8, 2013; revised April 18, 2013; accepted April 25, 2013.

Author contributions: V.S., D.L., and A.H. designed research; V.S. performed research; V.S., D.L., and A.H. analyzed data; V.S. and A.H. wrote the paper.

This work was funded by the following sources: the EC FP7 Grant "Plasticise", Swiss National Science foundation (CRSI33-127289 and NCCR/SYNAPSY), the IRP, the Novartis Foundation, and the Hans Wilsdorf foundation. We thank Jerome Randall, Simon Borgeaud, and Michel Cane for help with 2PLSM imaging; Simon Borgeaud, Luciana Nuovo Nunes, and Gauhar Masgutova for help with image analysis; Mark Hübener for discussions regarding IOS imaging; and Egbert Welker for help with surgical techniques.

The authors declare no competing financial interests.

Correspondence should be addressed to Dr Anthony Holtmaat, Department of Basic Neurosciences, Geneva Neuroscience Center, University of Geneva, 1 rue Michel-Servet, 1211 Geneva, Switzerland. E-mail: anthony.holtmaat@unige.ch.

DOI:10.1523/JNEUROSCI.1032-13.2013

Copyright $\odot 2013$ the authors $\quad 0270-6474 / 13 / 339474-14 \$ 15.00 / 0$
}

in the turnover of synaptic structures without affecting synaptic densities. Permanent deafferentation, on the other hand (e.g., retinal lesions or amputations) is thought to cause more robust alterations, such as synaptic density changes and neurite sprouting (Hickmott and Ethell, 2006; Holtmaat and Svoboda, 2009). Indeed, sprouting of deprived dendritic or spared axonal branches could greatly leverage cortical plasticity (Chklovskii et al., 2004), and support the expansion of the spared sensory modality's functional cortical domain well beyond the typical projection zone of its thalamocortical and intracortical efferents (Navarro et al., 2007). Several studies based on fixed brain tissue and group-wise comparisons over different animals have provided evidence for deafferentation-mediated reorganizations in dendritic and axonal projections in the adult cortex (DarianSmith and Gilbert, 1994; Florence et al., 1998; Kossut and Juliano, 1999; Hickmott and Steen, 2005; Tailby et al., 2005). Recent time-lapse in vivo imaging studies have lent support to the idea that intracortical axonal sprouting could underlie sensory deprivation-mediated map plasticity (Yamahachi et al., 2009; Marik et al., 2010). Thus far, experience-dependent changes in pyramidal cell dendrite organization have not been quantified and assessed in real time in conjunction with functional map shifts in the same animals. In addition, dendritic spine dynamics in the barrel cortex have not been studied after complete and permanent removal of sensory input. Therefore, it is as yet unclear how dendrites support extensive cortical map plasticity after irreversible whisker deprivation. Here we report that peripheral nerve deafferentation, as inflicted by whisker follicle removal (FR), evokes large-scale changes in somatosensory functional maps, without altering the gross structure of L2/3 and L5 pyra- 
midal cell dendrites. Structural changes remained confined to minor dendrite tip retractions and protractions. Tips of L5 cells tended to stabilize after deprivation. Dendritic spines, on the other hand, displayed long-term plasticity. L2/3 cells, which thus far have not been reported to display experience-dependent spine plasticity, showed enhanced new spine stabilization in our paradigm. This spine plasticity coincided with the map shifts that are also thought to occur in layer $2 / 3$. Together, our data suggest that peripheral nerve deafferentation-induced receptive field changes in the cortex are not associated with large-scale rearrangements of apical pyramidal cell dendrites and are likely supported by small-scale and local structural changes, such as the generation of new spines.

\section{Materials and Methods}

\section{Animals and cranial windows}

We used 26 (15 ctrl, 11 FR) adult (PND 84) mice of either sex. We performed initial intrinsic optical signals (IOS) mapping on 22 animals (11 ctrl, $11 \mathrm{FR})$. The position of the imaged cells inside the barrel field of remaining $4 \mathrm{ctrl}$ animals was verified using postmortem histology (Holtmaat et al., 2006; Wilbrecht et al., 2010). For this, the animals were perfused with $4 \%$ paraformaldehyde, the brains were extracted, and 100$\mu \mathrm{m}$-thick sections tangential to the barrel field were cut. The blood vessels were used to align the sections to the vasculature maps from in vivo images, to locate the imaged cell (data not shown) (Table 1).

Of the 26 mice, 12 (7 ctrl, 5 FR) were used for 2PLSM imaging only, and 7 ( $6 \mathrm{ctrl}, 1 \mathrm{FR}$ ) were used for quantitative IOS imaging only. Seven mice $(2 \mathrm{ctrl}, 5 \mathrm{FR})$ were used for combined 2PLSM and IOS. For a list of animals and experimental conditions, see Table 1. All experiments were performed according to the guidelines of the Swiss Federal Act on Animal Protection and Swiss Animal Protection Ordinance. The ethics committee of the University of Geneva and the Cantonal Veterinary Office (Geneva, Switzerland) approved all experiments.

Cranial windows were implanted overlying the left barrel cortex, as previously described (Holtmaat et al., 2009). Imaging was started 5 weeks after window implantation (average PND 134) (see Fig. 1A).

\section{Mouse lines}

For 2PLSM purposes, we used adult C57BL/6J transgenic mice $(n=18 ; 9$ ctrl and 9 FR) expressing eGFP under control of the Thy- 1 promotor (line M) (Feng et al., 2000). In the cortex of Thyl-eGFP transgenic mice the majority of the eGFP + pyramidal cells are located in L5 and occasionally in L2/3. Whenever mice contained sufficiently bright L2/3 cells we included them in our dataset. To increase the total number of L2/3 cells we supplemented our data with cells that were imaged in a tdTomato-expressing cre reporter mouse strain (TdT mice; line Ail4: Cg-Gt(ROSA)26Sor-CAG-LSL-TdTomato (Madisen et al., 2010); purchased from The Jackson Laboratory; $n=1$ ). The cre recombinase expression in this mouse was mediated by local injections of adenoassociated viral Cre-expression vector (AAV2/9.CMV.PI.Cre.rBG; $\sim 10$ $\mathrm{nl}$ total volume, titer $9.26 \times 10^{12}$, UPenn vector core). AAV vectors were injected at a depth of $200 \mu \mathrm{m}$ below the cortical surface 5 weeks before the imaging experiments concomitant to placing the cranial window (3.5 $\mathrm{mm}$ lateral and $1.5 \mathrm{~mm}$ distal to bregma) using a stereotaxic apparatus and a glass micropipette attached to a hydraulic injection system.

\section{Acquisition of intrinsic optical signal images}

IOS images were recorded using a stable halogen light source $(100 \mathrm{~W})$ in combination with a light guide system and a $700 \mathrm{~nm}$ interference filter (30 nm bandwidth) (Accolla et al., 2007). Mice were kept under light anesthesia ( $1 \%$ isoflurane at continuous oxygen flow) using a custommade mask, covering the animal's snout while leaving the right whisker pad freely accessible and the whiskers in their natural position. The head of the animal was kept in place with a nose clamp and the body temperature was kept constant with a heating pad. At the beginning of each imaging session, an image of the brain's surface vasculature was taken using green light (546 $\mathrm{nm}$ interference filter). Images were recorded using a VDAQ Imager 3001 system (Optical Imaging) equipped with a low
Table 1. List of animals and experimental conditions

\begin{tabular}{|c|c|c|c|c|c|c|c|c|}
\hline Mouse $\mathrm{Nr}$ & Condition & Labeling & Mapping & QIOS & 2PLSM & Cell No. & Layer & Position \\
\hline \multirow[t]{2}{*}{1} & CTRL & GFP & IOS & + & + & 1 & 5 & $\mathrm{BC}$ \\
\hline & & & & & & 2 & & $\mathrm{BC}$ \\
\hline \multirow[t]{2}{*}{2} & CTRL & GFP & IOS & - & + & 3 & 5 & $\mathrm{BC}$ \\
\hline & & & & & & 4 & & $\mathrm{BC}$ \\
\hline 3 & CTRL & GFP & HIST & - & + & 5 & 5 & $\mathrm{BC}$ \\
\hline \multirow[t]{2}{*}{4} & CTRL & GFP & HIST & - & + & 6 & 5 & $\mathrm{BC}$ \\
\hline & & & & & & 7 & & $B C$ \\
\hline 5 & CTRL & GFP & HIST & - & + & 8 & 5 & $B C$ \\
\hline \multirow[t]{3}{*}{6} & CTRL & GFP & HIST & - & + & 9 & $2 / 3$ & $B C$ \\
\hline & & & & & & 10 & & $\mathrm{BC}$ \\
\hline & & & & & & 11 & & BC-B \\
\hline \multirow[t]{2}{*}{7} & CTRL & GFP & IOS & - & + & 12 & $2 / 3$ & $\mathrm{BC}$ \\
\hline & & & & & & 13 & & $\mathrm{BC}$ \\
\hline \multirow[t]{2}{*}{8} & CTRL & GFP & IOS & + & + & 14 & 5 & $B C$ \\
\hline & & & & & & 15 & & $B C$ \\
\hline 9 & CTRL & GFP & IOS & - & + & 16 & $2 / 3$ & $B C$ \\
\hline \multirow[t]{8}{*}{10} & FR & GFP & IOS & - & + & 17 & $2 / 3$ & $D$ \\
\hline & & & & & & 18 & & D \\
\hline & & & & & & 19 & & D \\
\hline & & & & & & 20 & & $S$ \\
\hline & & & & & & 21 & 5 & $S$ \\
\hline & & & & & & 22 & $2 / 3$ & D \\
\hline & & & & & & 23 & & $S$ \\
\hline & & & & & & 24 & & $S$ \\
\hline \multirow[t]{4}{*}{11} & $F R$ & GFP & IOS & + & + & 25 & 5 & D \\
\hline & & & & & & 26 & & D \\
\hline & & & & & & 27 & & $S$ \\
\hline & & & & & & 28 & & $S$ \\
\hline 12 & $F R$ & GFP & IOS & + & + & 29 & $2 / 3$ & D \\
\hline \multirow[t]{3}{*}{13} & $F R$ & GFP & IOS & + & + & 30 & $2 / 3$ & $S$ \\
\hline & & & & & & 31 & & D \\
\hline & & & & & & 32 & & D \\
\hline \multirow[t]{2}{*}{14} & $F R$ & GFP & IOS & - & + & 33 & 5 & D \\
\hline & & & & & & 34 & $2 / 3$ & D \\
\hline \multirow[t]{3}{*}{15} & $F R$ & GFP & IOS & - & + & 35 & 5 & D \\
\hline & & & & & & 36 & & D \\
\hline & & & & & & 37 & & $D$ \\
\hline \multirow[t]{2}{*}{16} & $F R$ & GFP & IOS & - & + & 38 & 5 & D \\
\hline & & & & & & 39 & & D \\
\hline \multirow[t]{4}{*}{17} & $F R$ & GFP & 105 & + & + & 40 & 5 & $S$ \\
\hline & & & & & & 41 & & $S$ \\
\hline & & & & & & 42 & & $S$ \\
\hline & & & & & & 43 & & $S$ \\
\hline \multirow[t]{3}{*}{18} & $F R$ & GFP & IOS & - & + & 44 & 5 & $S$ \\
\hline & & & & & & 45 & & $S$ \\
\hline & & & & & & 46 & $2 / 3$ & $S$ \\
\hline \multirow[t]{6}{*}{19} & $F R$ & TDT & IOS & + & + & 47 & $2 / 3$ & $D$ \\
\hline & & & & & & 48 & & D \\
\hline & & & & & & 49 & & $S$ \\
\hline & & & & & & 50 & & $S$ \\
\hline & & & & & & 51 & & D \\
\hline & & & & & & 52 & & $D$ \\
\hline 20 & FR & - & IOS & + & - & n.a. & n.a. & n.a. \\
\hline 21 & CTRL & - & IOS & + & - & n.a. & n.a. & n.a. \\
\hline 22 & CTRL & - & IOS & + & - & n.a. & n.a. & n.a. \\
\hline 23 & CTRL & - & IOS & + & - & n.a. & n.a. & n.a. \\
\hline 24 & CTRL & - & IOS & + & - & n.a. & n.a. & n.a. \\
\hline 25 & CTRL & - & IOS & + & - & n.a. & n.a. & n.a. \\
\hline 26 & CTRL & - & IOS & + & - & n.a. & n.a. & n.a. \\
\hline
\end{tabular}

BC, Barrel cortex; BC-B, barrel cortex border; CTRL, control; $D$, deprived barrel columns; FR, follicle removal; HIST, histology; IOS, intrinsic optical signals; n.a., not applicable; Q1OS, quantitative IOS imaging; S, spared barrel columns; 2PLSM, two-photon laser scanning microscopy. 
read noise charge-coupled device (CCD) camera (1M pixel, $50 \mathrm{fps}, 10$ bit). The camera was attached to a $2.7 \times$ magnifying macroscope tandem lens (upper lens: Nikon $135 \mathrm{~mm}, f=2.0$; bottom lens: Nikon $50 \mathrm{~mm}, f=$ 1.2). The CCD camera was focused on a plane $300 \mu \mathrm{m}$ below the cortical surface. Images were acquired at $10 \mathrm{~Hz}$ for $5 \mathrm{~s}$, with a spatial resolution of $2.75 \mu \mathrm{m} /$ pixel comprising a total area of $2.7 \times 2.7 \mathrm{~mm}^{2}$. Single whiskers were deflected using a glass-capillary attached to a piezoelectric actuator (PL-140.11 bender controlled by a E-650 driver; Physik Instrumente) that was triggered by a pulse stimulator (Master-8, A.M.P.I.). Each trial consisted of a $1 \mathrm{~s}$ baseline period (frames 1-10), followed by a response period (frames 11-50), which included a $1.125 \mathrm{~s}$ stimulus period (frames 11-22) and a poststimulus period (frames $23-50$ ). The visible IOS response typically spanned frames 15-39. Intertrial intervals lasted $20 \mathrm{~s}$.

\section{In vivo barrel map estimation and cell localization}

To noninvasively identify the home barrel columns of all imaged cells, we mapped the IOS responses of 2-3 whiskers per mouse and extrapolated the position of the remaining barrels using a standard barrel map (Fig. 1).

The standard barrel map was obtained from Nissl-stained cortical sections of mice with a similar age and weight. For each mouse, we recorded 6-10 trials per whisker, superimposed the responses onto the blood vasculature using a different color for each whisker, and fitted the standard barrel map onto the responses. This allowed us to extrapolate the position of the remaining barrels relative to the surface vasculature, and in a second step to estimate the home barrel columns of all imaged cells. For L2/3 cells the home barrel estimation was based on the position of the cell body. For L5 cells we used the location of the first bifurcation in the apical dendrite tuft (Holtmaat et al., 2006; Wilbrecht et al., 2010).

\section{Quantitative analysis of intrinsic optical signal images}

For quantitative IOS measurements we recorded an average of 46 trials per session.

We model the IOS as:

$$
p(x, y, t) \equiv \bar{g}(x, y)+r(x, y, t) \bar{g}(x, y),
$$

where $p$ is the measured pixel value, $\bar{g}$ is the average background pixel value and $r$ is the pixel value of the response of interest ( $x$ and $y$ represent the pixel coordinates, and $t$ the time) (Kinoshita et al., 2009). The background pixel value was defined as the average of the frames previous to stimulus onset:

$$
\bar{g}(x, y) \equiv \frac{1}{10} \sum_{f=1}^{10} p\left(x, y, t_{f}\right)
$$

We then divided $p$ by $\bar{g}$ and solve for $r$ :

$$
r(x, y, t)=\frac{p(x, y, t)}{\bar{g}(x, y)}-1 .
$$

The responses of different sessions from the same animal were spatially aligned using the animal's brain surface vasculature. After aligning the different sessions, the pixels were spatially binned $(6 \times 6$, final resolution: $16.5 \mu \mathrm{m} /$ pixel). We then applied a high pass filter by subtracting from each image-frame the same image-frame that was convolved with a 750 $\mu \mathrm{m}$ full-width at half $\max$ (FWHM) Gaussian kernel. For each trial, we divided the signal into an average evoked response $(0.9-1.9 \mathrm{~s}$ from stimulus onset, frames 19-28):

$$
\bar{s}(x, y)=\frac{1}{10} \sum_{f=19}^{28} r\left(x, y, t_{f}\right)
$$

and average baseline ( -1 to $0 \mathrm{~s}$ from stimulus onset, frames 1-10):

$$
\bar{b}(x, y)=\frac{1}{10} \sum_{f=1}^{10} r\left(x, y, t_{f}\right)
$$

The spatial binning, high pass filtering and the temporal averaging substantially increased the signal-to-noise ratio.

Response areas. We estimated the whisker evoked response area using a pixel-by-pixel paired $t$ test, comparing $s$ and $b$ over all trials within a session. This resulted in a $t$ value map for every session. To avoid introducing spatial correlations (Reimold et al., 2006), we performed spatial smoothing only after creating the $t$ maps. The $t$ maps were low pass filtered with a $200 \mu \mathrm{m}$ FWHM Gaussian kernel after which the two following criteria were applied: (i) a threshold was set to $t<-2.0$. Anything below this $t$ value was considered to belong to the stimulus-evoked response area, and $t$ values equal to and above this value were discarded. This usually resulted in an image with a clear minimum, representing the response maximum. There were cases in which additional minima appeared at the edge of the cranial window, and were clearly artifacts. To remove these artifacts, we developed a masking algorithm (ii) that ignored outlying pixels with $t<-2.0$ that were $>750 \mu \mathrm{m}$ away from the max response along with any contiguous pixels, iteratively using spatial derivatives. If contiguous pixels were closer than $550 \mu \mathrm{m}$ from the max response, we removed the dataset ( 1 case) from the analysis, as it would violate our assumption that deflection of a single whisker evokes a single peak. Based on the pixels that remained after setting criteria (i) and (ii) we estimated the maximum response position (the center of mass of the $2 \%$ lowest-valued pixels) and the area of the response (the summation of the area of all pixels crossing threshold). If areas were smaller than 0.01 $\mathrm{mm}^{2}$ we assumed that the experiment had failed and consequently excluded the data from the analysis. Typical response area estimates were larger than the anatomical barrel column (due to the $t$ value threshold and a $200 \mu \mathrm{m}$ FWHM Gaussian kernel, which were optimal for robust area estimates over time) (Rosenfeld et al., 1982; Reimold et al., 2006).

Response area changes. For each whisker we measured response areas during the baseline period $\left(\mathrm{A}_{\text {start }}\right)$ (Fig. 1A) (except $1 \mathrm{ctrl}$ whisker for which $A_{\text {start }}$ was at day 22$)$, and at the end of the experiment $\left[\left(A_{\text {end }}\right)\right.$ average $\Delta$ time $=65.4 \pm 3 \mathrm{~d}(\mathrm{ctrl})$ and $64 \pm 3 \mathrm{~d}(\mathrm{FR})]$. To evaluate the changes in response areas over time, we calculated the ratio between $A_{\text {end }}$ and $\mathrm{A}_{\text {start }}$. We used three additional criteria for selecting data that was suitable for calculating changes in the response area: (iii) max response position distance between sessions should not exceed $150 \mu \mathrm{m}$ (iv) a minimum response area of $0.01 \mathrm{~mm}^{2}$ (112 $\mu \mathrm{m}$ diameter circle) was required, and (v) only animals that were recorded between 40 and $90 \mathrm{~d}$ $(40 \leq n \leq 90)$ after FR were included. These criteria insured that we were always taking into account the same whiskers (criterion iii), and that we were using successful IOS measurements (criterion iv).

Response expansion into deprived cortex. To estimate the expansion of IOS response into the deprived cortex, we selected datasets that contained multiple sessions and that had survived criteria (iii), (iv), and (v). From this subset we further selected those animals that had both whiskers $\mathrm{C} 1$ and $\mathrm{C} 2$ mapped before whisker FR. We used the maximum response positions of these 2 whiskers from before ablation:

$$
\left[\begin{array}{l}
x_{c 1} \\
y_{c 1}
\end{array}\right] \text { and }\left[\begin{array}{l}
x_{c 2} \\
y_{c 2}
\end{array}\right]
$$

to find the angle $\theta$ between them:

$$
\theta=\tan ^{-1}\left(\frac{y_{c 1}-y_{c 2}}{x_{c 1}-x_{c 2}}\right),
$$

(see Fig. 3A), and used the following rotation:

$$
\left[\begin{array}{l}
x_{i}^{\prime} \\
y_{i}^{\prime}
\end{array}\right]=\left[\begin{array}{c}
\cos (\theta) \sin (\theta) \\
-\sin (\theta) \cos (\theta)
\end{array}\right] \times\left[\begin{array}{l}
x_{i} \\
y_{i}
\end{array}\right],
$$

to rotate the position vectors by the angle $\theta$ in a left-handed Cartesian coordinate system (see Fig. $3 B$ ), and set the angle between C1 and C2 to 0 radians for all animals. We then performed the translation:

$$
\left[\begin{array}{l}
x_{i}^{\prime \prime} \\
y_{i}^{\prime \prime}
\end{array}\right]=\left[\begin{array}{l}
x_{i}^{\prime} \\
y_{i}^{\prime \prime}
\end{array}\right]-\left[\begin{array}{l}
x_{c}^{\prime} \\
y_{c}^{\prime}
\end{array}\right]
$$

to align the maximum responses of all whiskers from all animals and center them at the origin (see Fig. 3B).

We created a spatial probability distribution of the aligned whisker response areas. To quantify the expansion into the deprived cortex, we set different thresholds over the ordinate axis at regular intervals covering a distance up to $500 \mu \mathrm{m}$ from the maximum response. We then calculated 
the response area above each threshold for every whisker and compared the expansion areas between deprived and control cortices.

All data analyses were performed using custom software written in MATLAB (The MathWorks).

Two-photon laser-scanning microscopy

In vivo images were acquired under mild isoflurane-anesthesia using a custom built-two-photon laser-scanning microscope (2PLSM) (Holtmaat et al., 2005, 2009) controlled by custom software written in MATLAB (Scanimage, Janelia Research Farm) (Pologruto et al., 2003). As a light source we used a tunable Ti:sapphire laser (Chameleon ultra II, Coherent) running at $\sim 910 \mathrm{~nm}$ to image EGFP and $\sim 1040 \mathrm{~nm}$ for TdTomato. The microscope was equipped with a $40 \times, 0.8$ NA objective (Olympus) and high quantum efficiency-photomultiplier tubes (R3896, Hamamatsu). In each animal we selected 1-8 L2/3 and/or L5 cells and imaged their apical dendritic tufts that ramified in L1/L2. For some L2/3 pyramidal neurons we also imaged basal dendrites. Dendrites were repeatedly imaged over a minimum period of $63 \mathrm{~d}$, with $7 \mathrm{~d}$ intervals during the first $35 \mathrm{~d}$ and with $14 \mathrm{~d}$ intervals for the remainder of the experiment. For the purpose of measuring dendritic length changes we acquired image stacks (with a field of view of $\sim 128 \times \sim 128 \mu \mathrm{m}$, and 1 $\mu \mathrm{m}$ steps between planes) at a resolution of $0.25 \mu \mathrm{m} /$ pixel and a $3.9 \mu \mathrm{s}$ pixel dwell time. For quantifying spine dynamics, image stacks (field of view, $\sim 51 \times 51 \mu \mathrm{m}, 1 \mu \mathrm{m}$ steps) were acquired at $0.1 \mu \mathrm{m} /$ pixel and 3.9 $\mu$ s pixel dwell times.

\section{Whisker follicle removal}

To permanently remove whisker sensory inputs, the first four vibrissae follicles of rows D and E, together with $\gamma$ and $\delta$ were removed from the whisker pad contralateral to the imaged hemisphere ( $n=11$ mice). Mice were anesthetized using an intraperitoneal injection of a Ketamine/Xylazine mixture ( 0.10 and $0.01 \mathrm{mg} / \mathrm{g}$ body weight, respectively). Incisions were made in the skin ventral to the targeted follicles. Each follicle was isolated from the surrounding connective tissue using surgical tweezers and pulled out from underneath the skin. We verified that each follicle had been removed completely, leaving the respective branch of the follicular nerve severed. The incision in the skin was closed using surgical glue (Vetbond). Postsurgical analgesia (buprenorphine) was administered subcutaneously. Over the following days, the mice were monitored closely to verify that the wounds healed, the remaining whiskers could be properly moved, and were engaged in active whisking. Whiskers never regrew after the surgery, indicating that the follicles were successfully removed.

\section{Image analysis}

Terminal branch dynamics. Length changes of individual dendrites were measured in three dimensions using Neurolucida Software (Image Stack extension Module, MBF Biosciences). Tips were traced starting either at the closest branch point, or at a fiducial point on the dendrite (e.g., particular curvatures or a cluster of big spines that were not dynamic). The length of each tip was measured in an identical manner at day $0\left(\mathrm{~L}_{\mathrm{d} 0}\right)$ and at day $56\left(\mathrm{~L}_{\mathrm{d} 56}\right)$. The length change was calculated as the difference between the two time points $\left(\Delta \mathrm{L}_{\text {tips }}=\mathrm{L}_{\mathrm{d} 56}-\mathrm{L}_{\mathrm{d} 0}\right)$. Note: cells of which $<$ 3 tips were measured were excluded from the analysis shown in Figure $4 E, F$.

Inter-branch point segment dynamics. We estimated length changes due to errors in measurements and movement artifacts, similar to methods previously used for the analysis of axonal dynamics (De Paola et al., 2006) (see Fig. 4C). We measured length changes between two dendritic branch points in control and deprived animals $\left(\Delta \mathrm{L}_{\mathrm{BP}}\right)$ over a 56 day interval. We calculated the $\mathrm{SD}$ of $\Delta \mathrm{L}_{\mathrm{BP}}\left(\sigma_{\mathrm{BP}}\right)$ and set a threshold for significant retractions $\left(\Delta \mathrm{L}_{\mathrm{BP}}-3 \times \sigma \mathrm{BP}\right)$ and protractions $\left(\Delta \mathrm{L}_{\mathrm{BP}}+3 \times \sigma \mathrm{BP}\right)$ of tips.

Reconstruction of dendrite tufts. Dendrite tufts were reconstructed in three dimensions from individual image stacks using Neurolucida Software (Image Stack extension Module, MBF Biosciences). We measured various parameters of dendrite organization and complexity for individual tufts before (day -7 to 0 ) and after FR (day 56-84). We compared the values obtained for each tuft, by calculating the ratio (day -7 to 0)/(day 56-84) for all parameters. Dendrite tufts comprised all branches including branch points. They were only included in the analysis of
Table 2. Number of cells (mice) used for individual experiments

\begin{tabular}{|c|c|c|c|c|c|c|}
\hline & \multicolumn{3}{|l|}{$L 2 / 3$} & \multicolumn{3}{|l|}{$\mathrm{L} 5$} \\
\hline & \multirow[b]{2}{*}{ CTRL } & \multicolumn{2}{|l|}{$F R$} & \multirow[b]{2}{*}{ CTRL } & \multicolumn{2}{|l|}{$F R$} \\
\hline & & depr & spared & & depr & spared \\
\hline Tips (individual) & $5(3)$ & $10(5)$ & $7(4)$ & $10(6)$ & $8(4)$ & $9(4)$ \\
\hline Tips (cells) & $5(3)$ & $6(5)$ & $4(3)$ & $10(6)$ & $8(4)$ & $7(4)$ \\
\hline Dendrite (complexity) & $5(2)$ & $5(2)$ & & $6(4)$ & $10(5)$ & \\
\hline Dendrite (length) & $5(2)$ & $5(2)$ & & $5(3)$ & $10(5)$ & \\
\hline Spines & $5(2)$ & $5(4)$ & $5(4)$ & $9(6)$ & $8(4)$ & $5(3)$ \\
\hline
\end{tabular}

Total number of cells (mice) used for statistical comparison between experimental groups displayed in Figures 4-6. Tips (individual): Figure $4 B, D$; tips (cells), Figure $4 E, F$; dendrite (complexity) and dendrite (length), Figure $5 F$; spines, Figure 6. Ctrl, Control; FR, follicle removal; depr, deprived.

branch order, branch number, and tortuosity if they were clearly visible at all time points. Similarly, measurement of tuft length was restricted to dendrites of which all tips were clearly visible at both time points. L5 cell apical dendrite segments located below the main bifurcation were omitted from the analysis, due to the limited depth with which all dendrites could be imaged reliably. Similarly, we excluded L2/3 cell basal dendrites that vertically projected to deeper cortical layers, and of which we could not unequivocally determine the endings.

Spine analysis. Spines were scored as described and checked by an independent counter who was blind to all conditions (Holtmaat et al., 2009). Spine dynamics were computed over day -7 to 56 . We computed linear spine densities, spine turnover ratios, and new spine stabilization. Spine densities were normalized to the density on day 0 . The turnover ratio between two time points is defined as TOR $=\left(\mathrm{N}_{\text {gained }}+\mathrm{N}_{\text {lost }}\right) /(2 \times$ $\left.\mathrm{N}_{\mathrm{t} 1}\right)$. $\mathrm{N}_{\mathrm{t} 1}$ is the total number of spines present at the first time point. To quantify new spine stabilization we calculated the density of the sum of new spines that survived for $14 \mathrm{~d}$ or more over the entire imaging period [new persistent (NP) spines]. We counted spines on 22 L5 cells (ctrl, 9; depr, 8 ; spared, 5) and $15 \mathrm{~L} 2 / 3$ cells (ctrl, 5; depr, 5; spared, 5). In total we scored 4070 L5 cell spines (ctrl, 1398; depr, 970; spared, 1702), and 1678 L2/3 cell spines (ctrl, 468; depr, 843; spared, 367).

Statistics. For analysis of dendrite and spine data, unless stated otherwise, we used a Kruskal-Wallis test, followed by Dunn's test with correction for multi comparisons. Significance was set to $p<0.05$. Unless mentioned in the results, the number of cells and mice used for statistical comparisons are listed in Table 2.

\section{Results}

To concomitantly monitor functional and structural changes in the somatosensory cortex of adult mice over weeks and months after persistent sensory deprivation, we combined imaging of IOS (Grinvald et al., 1986; Bathellier et al., 2007) with in vivo twophoton laser-scanning microscopy (Holtmaat et al., 2009). We implanted cranial windows over the barrel cortex of adult mice expressing GFP or tdTomato in a subset of pyramidal cells (Feng et al., 2000). After a recovery phase of 3-4 weeks, we imaged whisker stimulation-evoked IOSs for a subset of whiskers (typically three) and superimposed the responses onto a bright-field image of the brain's surface vasculature (Fig. $1 A, B$ ). To identify the home barrel columns of all imaged cells we extrapolated the position of the remaining barrels relative to the blood vasculature using a standard barrel map (Fig. 1B).

We repeatedly imaged GFP-expressing L 5 and L2/3 pyramidal cell dendrites over several months and continued to monitor the IOS responses of $1-2$ whiskers in the $\mathrm{C}$ row (Fig. $1 B-D)$. After a baseline period of two imaging sessions ( $7 \mathrm{~d}$ interval) (Fig. $1 A$ ) we removed five whisker follicles in each of the two most ventral rows (whiskers $\gamma, \mathrm{D} 1-\mathrm{D} 4$ and $\delta$, E1-E4) (Fig. 1E). Such amputations irreversibly damage the peripheral trigeminal nerve endings and result in a profound deprivation of cortical inputs (Fig. $1 E, F)$ (Harris and Woolsey, 1981). This paradigm induces ro- 
A

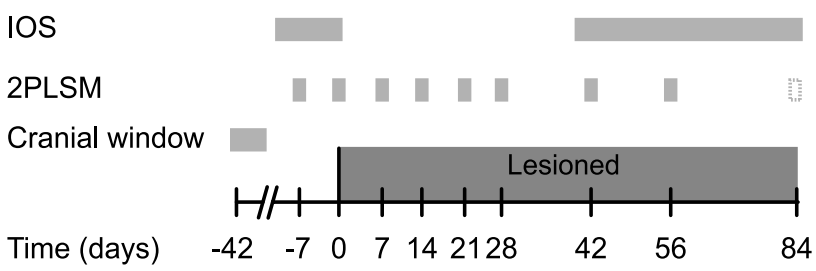

C
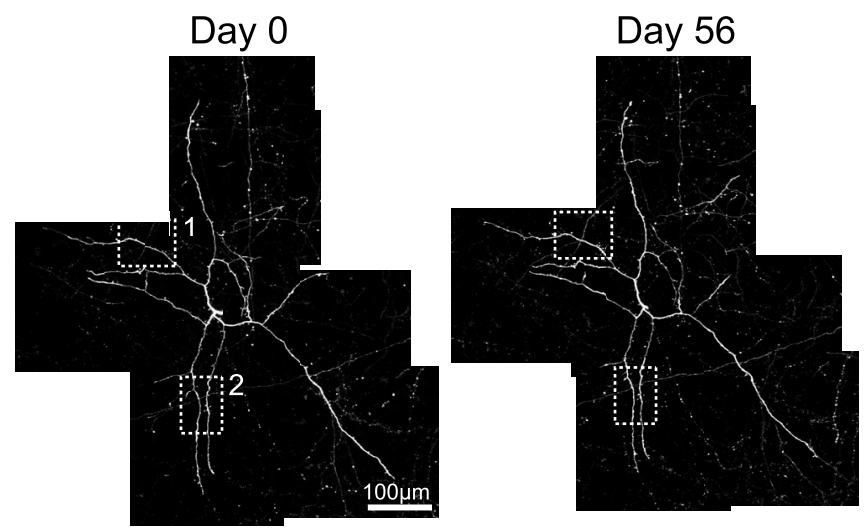

$E$
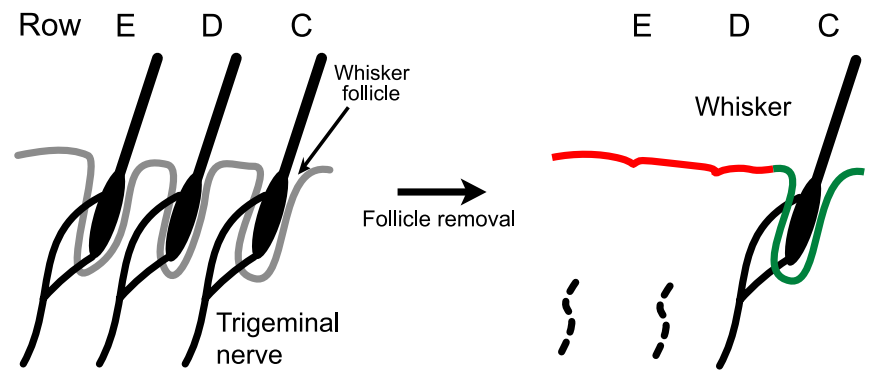

$\mathrm{B}$
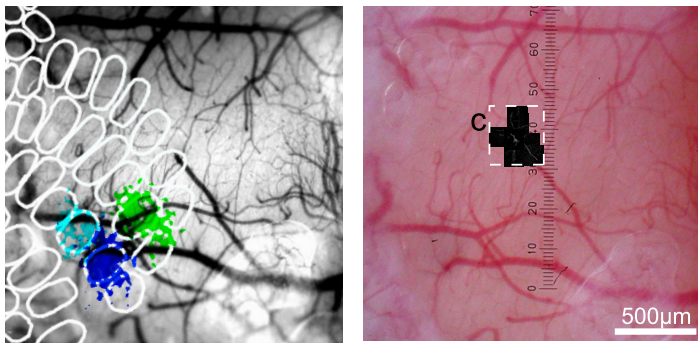

$\mathrm{D}$
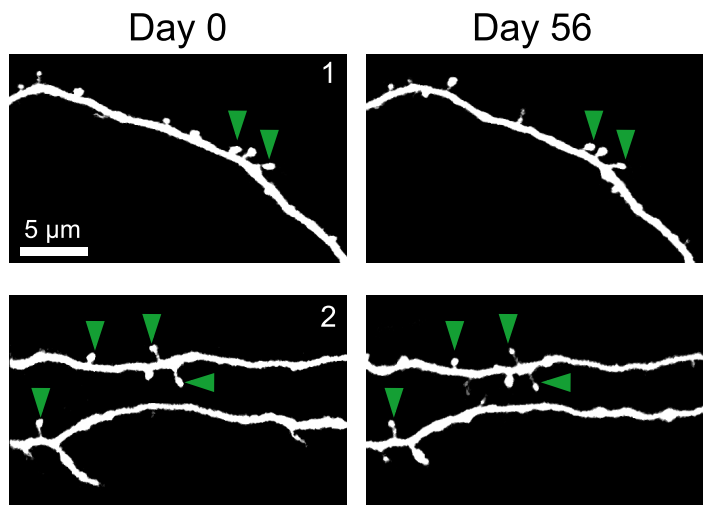

$\mathrm{F}$

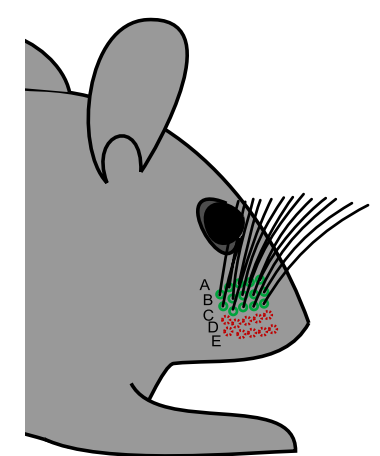

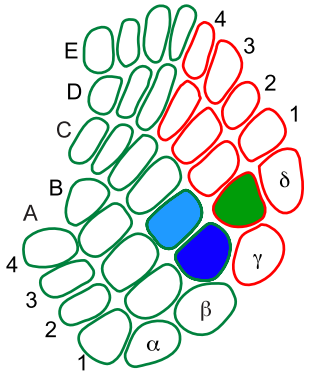

Figure 1. Experimental design. $A$, Experimental time course. $B$, Left panel, IOS responses to stimulation of individual whiskers are superimposed over the superficial vasculature (dark blue, $C 1$; light blue, (2; green, D1) and are used to position a standard map of the barrel field (barrels outlined in white). Right panel, GFP-expressing pyramidal cells are localized using 2PLSM and the position of the cells relative to the barrel map is determined. C, Overview of a $\mathrm{L} 5$ cell apical dendrite tuft imaged at days 0 and 56 . The center of the tuft is positioned in barrel E3 (B, boxed area). $\boldsymbol{D}$, Individual dendrite segments are imaged at high-magnification to monitor dendritic spine dynamics. The boxed areas in C indicate the position of the individual segments and arrowheads point to spines present over a $56 \mathrm{~d}$ time frame. $\boldsymbol{E}, \boldsymbol{F}$, Schematic illustrating the lesion paradigm. $\boldsymbol{E}$, The removal of whisker follicles lesions the trigeminal nerve endings and causes permanent whisker deprivation. $\boldsymbol{F}$, Side view of a mouse's snout after FR and the corresponding map of the contra-lateral barrel cortex. Note that a subset of whiskers is missing (red circles), whereas the remainder of the whiskers is left intact (green circles). This results in a partial deprivation of the barrel cortex (green, spared barrels; red, deprived barrels). The highlighted barrels correspond to the whiskers (C1, dark blue; $\mathrm{C2}$, light blue; D1, green) used to map the barrel columns. $C 1$ and $(2$ were used to measure map shifts with quantitative 105 measurements.

bust functional plasticity in neonates and adults (Kossut and Juliano, 1999; Dubroff et al., 2005).

Functional reorganization of the barrel cortex after follicle removal

To evaluate changes of individual spared whisker representations, we repeatedly and quantitatively measured whisker-evoked IOS responses within the same animal. We optimized our analytical methods to produce robust response area estimates, based on thresholded statistical maps. In every animal we compared the response area of each whisker at the beginning of the experiment $\left(\mathrm{A}_{\text {start }}\right)$ to the area at the end of an experiment $\left(\mathrm{A}_{\text {end }}\right)$. In control animals, whisker-evoked IOS response areas remained stable over months (Fig. $2 A, B)\left(\mathrm{A}_{\text {start }}=0.24 \pm 0.03 \mathrm{~mm}^{2} ; \mathrm{A}_{\text {end }}=\right.$ $0.23 \pm 0.03 \mathrm{~mm}^{2} ; p=0.77$, Mann-Whitney test). This corresponds to a circle with an average diameter $(\varnothing)$ of $560 \mu \mathrm{m}\left(\mathrm{A}_{\text {start }}\right)$, and $542 \mu \mathrm{m}\left(\mathrm{A}_{\text {end }}\right)$, respectively. After FR, the spared whiskerevoked IOS response area expanded on average almost twofold (Fig. $2 C, D)\left(\mathrm{A}_{\text {start }}=0.19 \pm 0.02 \mathrm{~mm}^{2} ; \mathrm{A}_{\text {end }}=0.35 \pm 0.03 \mathrm{~mm}^{2}\right.$; start: $\varnothing 494 \mu \mathrm{m}$; end: $\varnothing 672 \mu \mathrm{m}) ; p<0.005$, Mann-Whitney test). The ratio of these response areas $\left(A_{\text {end }} / A_{\text {start }}\right)$ was significantly larger after FR compared with controls (Fig. 2E) (median ratios: ctrl, 1.0; FR 1.9; $p<0.005$, Mann-Whitney test; $\mathrm{n}_{\text {whisker }} / \mathrm{n}_{\text {mice: }}$ : ctrl, 8/6; FR, 9/5). 
A

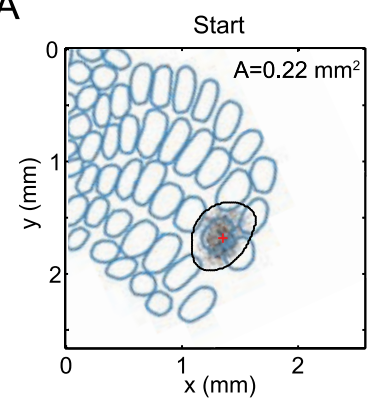

B

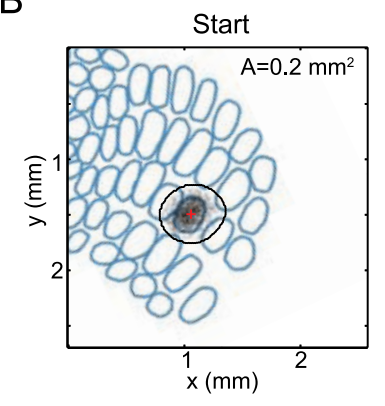

D

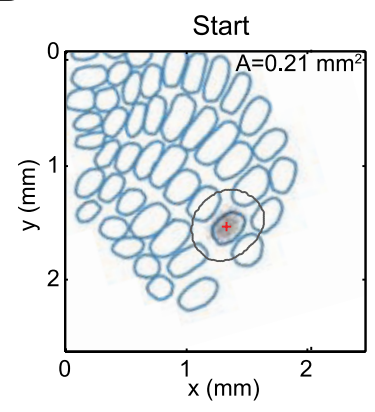

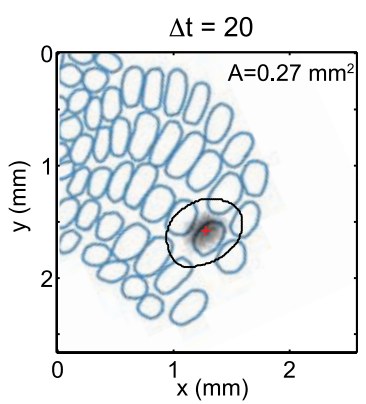

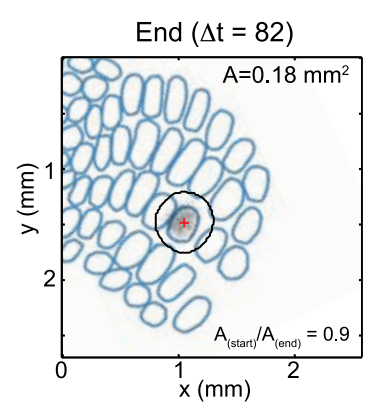

C

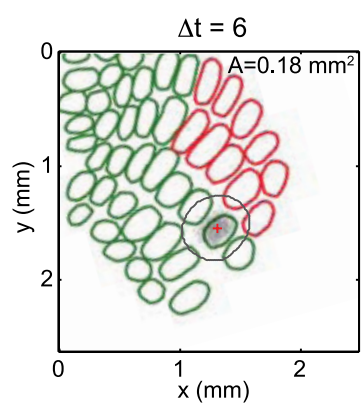

$\mathrm{E}$
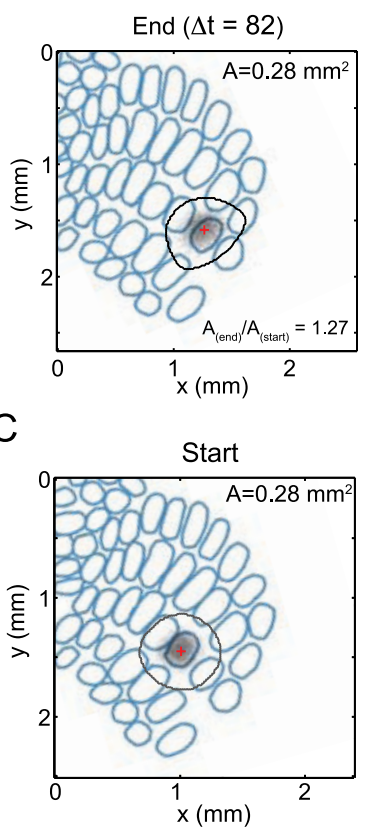

(
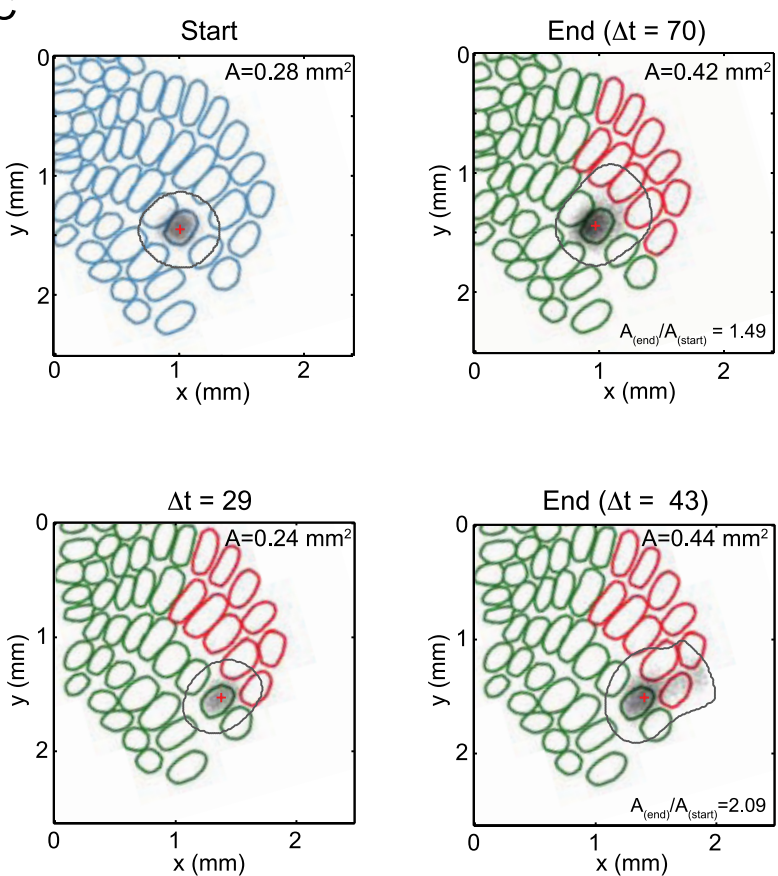

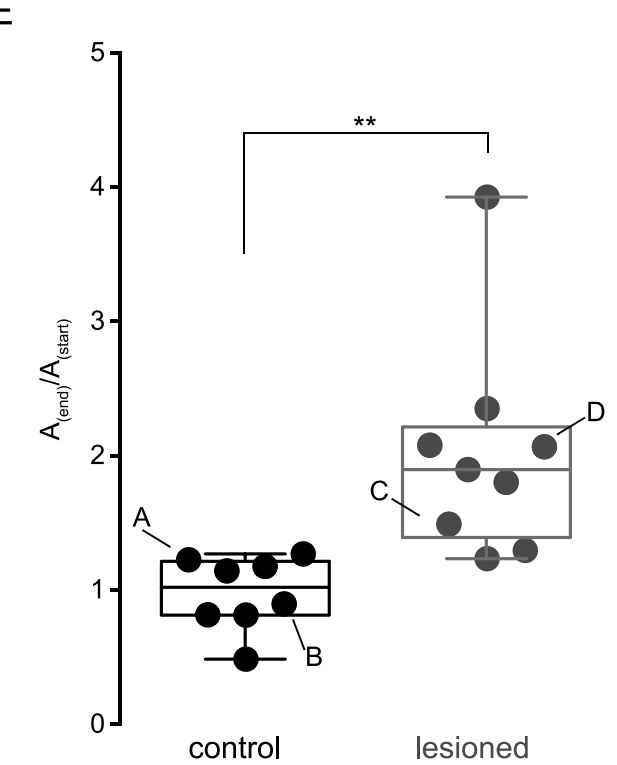

Figure 2. Expansion of spared whisker representations after FR. IOS responses to principal whisker stimulation repeatedly measured in the same animal. Thick lines delineate the response area (black, control; gray, FR animal). Red cross indicates the position of the maximum response. Examples of IOS response area (A) measured in control $(\boldsymbol{A}, \boldsymbol{B})$ and lesioned animals $(\boldsymbol{C}, \boldsymbol{D})$ over time. $\boldsymbol{E}$, Quantification of $I O S$ response area changes. For each whisker the ratio of the area at the end $\left(A_{\text {end }}\right)$ over the beginning $\left(A_{\text {start }}\right)$ of the experiment $\left(A_{\text {end }} / A_{\text {start }}\right)$ was calculated. Letters indicate values corresponding to the examples shown in $\boldsymbol{A}-\boldsymbol{D}$. Response areas for control animals are stable over time (median ratio $c t r l=1.0$ ). FR triggers the expansion of spared whisker representations (median ratio deprived $=1.9)$. ${ }^{* *} p<0.005$, Mann-Whitney. Note, the standard barrel maps displayed in this figure were placed for illustration purposes only. 
A

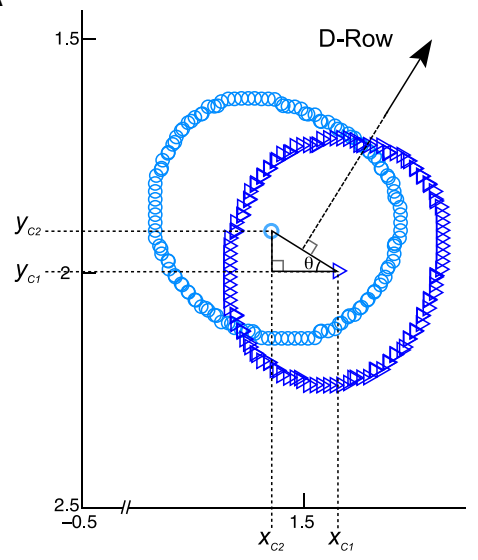

C

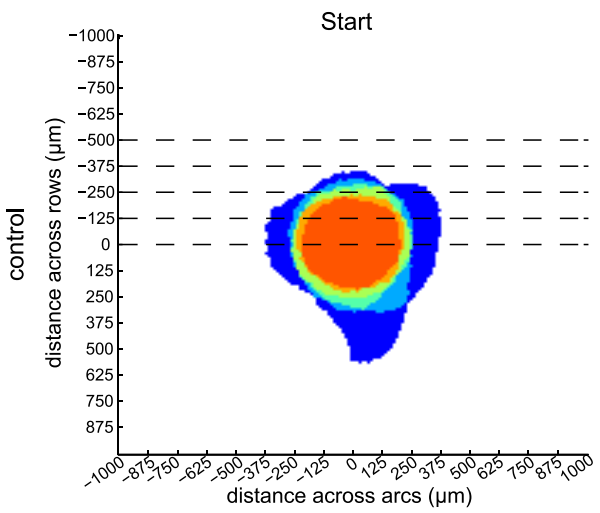

D

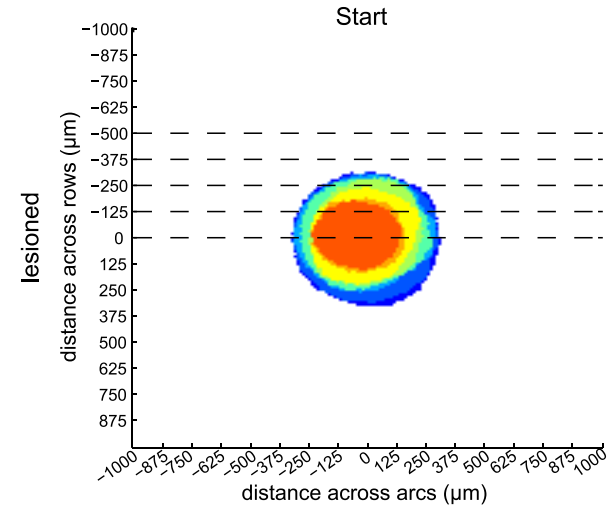

$\mathrm{E}$

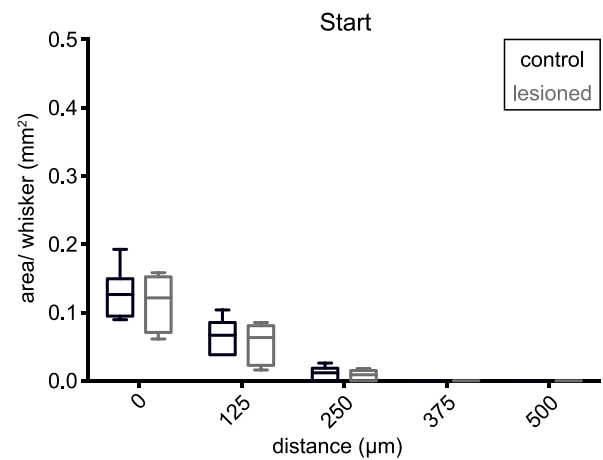

B

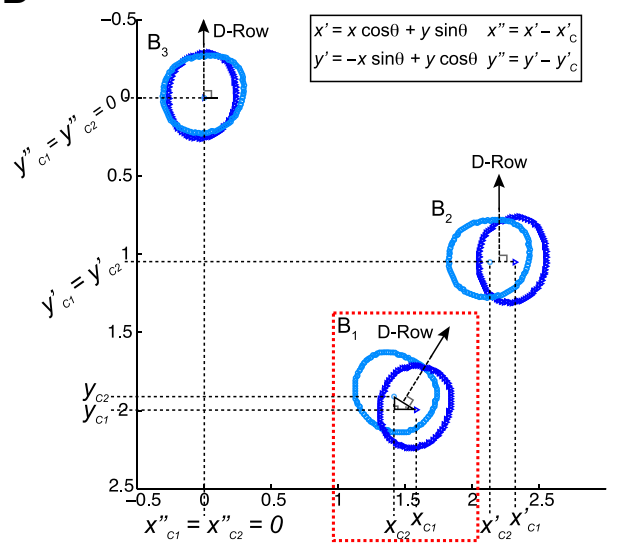

$\mathrm{B}_{3}$
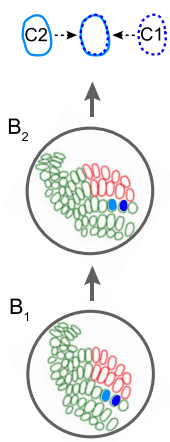
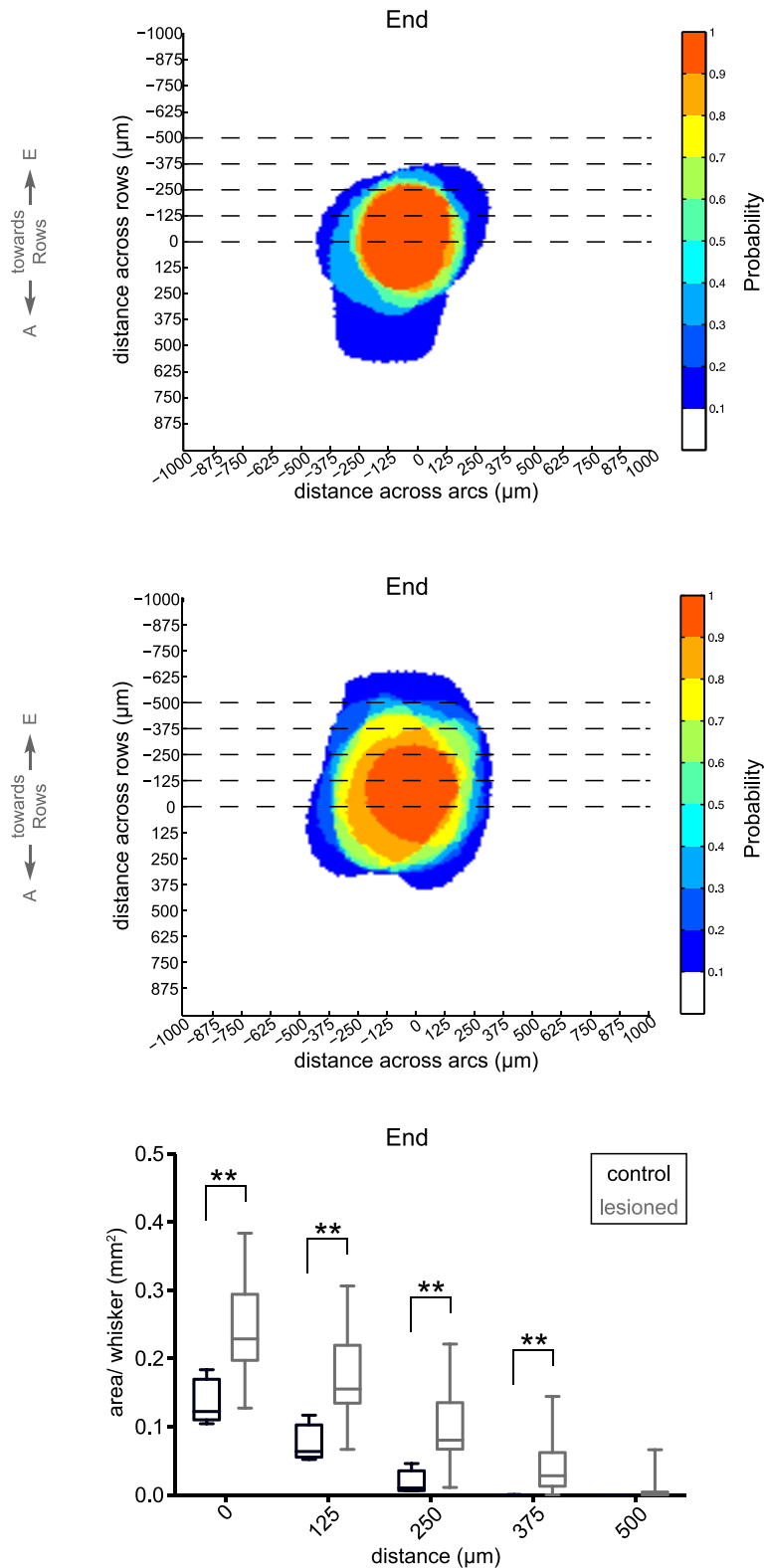

Figure 3. IOS responses expand into deprived barrel columns. Estimation of the expansion of spared whisker representations into deprived barrel columns. $\boldsymbol{A}, \boldsymbol{B}$, Schematic illustrating the transformation of individual IOS response areas into a common coordinate system. The max response of whiskers $C 1$ ( $\left[x_{\mathrm{C}_{1} 1} y_{\mathrm{c}}\right]$, dark blue) and $C 2$ ( $\left[x_{\mathrm{C}_{2}}, y_{\mathrm{C}_{2}}\right]$, light blue) were used to calculate the angle $\theta$ between them $\left(\boldsymbol{A}_{1}, \boldsymbol{B}_{1}\right)$. The IOS response areas were rotated by this angle $\left(\boldsymbol{B}_{2}\right)$ using the equations $x^{\prime}$ and $y^{\prime}$ shown in the inset. Subsequently the response areas were translated to the origin by subtracting their max responses $\left(x^{\prime \prime}\right.$ and $\left.y^{\prime \prime}\right)$. The position of the $D$ and E row (deprived) barrels was now constant for all whiskers and animals $\left(\boldsymbol{B}_{3}\right) . \boldsymbol{C}, \boldsymbol{D}$, To visualize the (Figure legend continues.) 
To quantify whether the spared whisker response area had significantly expanded into the deprived whisker territories, we used mice in which both the $\mathrm{C} 1$ and the $\mathrm{C} 2$ whisker responses were measured at the beginning of the experiment. The positions of the maximum IOS responses (max responses) were used to transform the response areas of all whiskers into a common coordinate system (Fig. $3 A, B$ ), in which the ordinate axis corresponds to distance within arcs from the center of the $C$ row toward the $\mathrm{D}$ and $\mathrm{E}$ rows. We used the aligned individual response areas to calculate a spatial probability distribution for each condition (Fig. 3C,D). We quantified expansions toward the deprived cortex for each whisker as the area exceeding particular thresholds along the ordinate axis (Fig. 3E). At the start of the experiments there was no significant difference between controls and lesioned animals (Fig. 3E). However, at the end significantly larger areas were observed at all thresholds up to $375 \mu \mathrm{m}$ (Fig. $3 E$; $)\left(\mathrm{n}_{\text {whisker }} / \mathrm{n}_{\text {mice }}\right.$ : $\left.\mathrm{ctrl}, 6 / 4 ; \mathrm{FR}, 8 / 4\right) ; p<0.005$, Mann-Whitney test). This indicates that spared whisker IOS responses had significantly expanded into the deprived rows of the barrel cortex. Thus, FR triggers a functional reorganization of the barrel map in adult mice.

\section{Large-scale structural stability of pyramidal cell dendrites}

To monitor large-scale structural dynamics of pyramidal cell dendrites, we repeatedly imaged entire dendritic arbors of L2/3 and L5 pyramidal cells. In a first step we compared the dynamics of individual dendrite terminal branch tips (hereafter referred to as tips) between control and lesioned animals. We observed minor protractions and retractions of both L2/3 and L5 tips (Fig. $4 A$ ). To quantify this we measured the overall length change for each tip $\left(\Delta \mathrm{L}_{\text {tips }}\right)$ over a 2 month period. In control animals, tips of $\mathrm{L} 2 / 3$ and $\mathrm{L} 5$ cells minimally retracted over time (median $\Delta \mathrm{L}_{\text {tips }}$, L5: $-4.8 \mu \mathrm{m}, \mathrm{L} 2 / 3:-2.0 \mu \mathrm{m}$ ) (Fig. $4 B$ ). FR significantly reduced the average $\Delta \mathrm{L}_{\text {tips }}$ of $\mathrm{L} 5$ cell dendrites in both deprived and spared cortical areas (median $\Delta \mathrm{L}_{\text {tips }} \mathrm{L} 5$ : deprived, $-1.7 \mu \mathrm{m}$; spared, $-1.8 \mu \mathrm{m}$; L2/3: deprived, $-1.15 \mu \mathrm{m}$; spared, $-0.75 \mu \mathrm{m} ; p<$ 0.005 , Kruskal-Wallis followed by Dunn's multiple-comparisons test). The dynamics were specific to tips because dendrite length between branch points (BPs) did not change under both conditions $\left(\Delta \mathrm{L}_{\mathrm{BP}}=-0.31 \mu \mathrm{m}\right)$ (Fig. $4 C$ ). This relative stability of inter-BP length allowed us to quantify the fraction of tips that underwent detectable growth and retraction. We computed the $\mathrm{SD}$ of $\Delta \mathrm{L}_{\mathrm{BP}}\left(\sigma_{\mathrm{BP}}=0.88 \mu \mathrm{m}\right)$ and set a threshold for significant retractions $\left(\Delta \mathrm{L}_{\mathrm{BP}}-3 \times \sigma_{\mathrm{BP}}=-2.94 \mu \mathrm{m}\right)$ and protractions $\left(\Delta \mathrm{L}_{\mathrm{BP}}+3 \times \sigma \mathrm{BP}=2.32 \mu \mathrm{m}\right)$ of tips. In controls, $\mathrm{L} 5$ but not $\mathrm{L} 2 / 3$ cell tips displayed a tendency toward retraction (growth, $1 \%$; stable, 35\%; retraction, 64\%) (Fig. 4D). FR disrupted this tendency leading to a larger amount of stable tips in both, deprived (growth, $6 \%$; stable, 52\%; retraction $42 \%$ ) and spared barrels (growth, 5\%;

\section{$\leftarrow$}

(Figure legend continued.) extent of whisker response expansions over time, we plotted histograms displaying the spatial response probability distribution for the $C 1$ and $C 2$ whiskers at the start $\left(A_{\text {start }}\right)$ and the end of the experiment $\left(A_{\text {end }}\right)$. Pixels that were present in all responses have a probability of 1.0. At the start, the probability distribution of IOS responses was similar between control and lesioned animals ( $\boldsymbol{C}, \boldsymbol{D}$, left panels). At the end of the experiment, this probability distribution was different ( $\boldsymbol{D}$, right panel). $\boldsymbol{E}$, Statistical comparison of the response area expansion in control and lesioned animals at the start (left panel) and the end (right panel) of the experiment. We used a set of thresholds along the ordinate axis to quantify the expansions toward the deprived cortex for each whisker. At the start of the experiment both groups showed similar areas crossing each of the thresholds. After FR animals displayed significantly larger average areas beyond the thresholds compared with controls. ${ }^{* *} p<0.01$ Mann-Whitney. stable, 62\%; retraction 33\%) (Fig. 4D). We next assessed how the length changes of individual dendrite tips were distributed across cells (Fig. $4 E, F$ ). FR did not change the average tip stability of L2/3 cells (Fig. $4 E$ ) (median $\Delta \mathrm{L}_{\text {tips }} \mathrm{L} 2 / 3$ : ctrl, $-3.53 \mu \mathrm{m}$; depr, $-1.067 \mu \mathrm{m}$; spared, $-0.68 \mu \mathrm{m})$. L5 cells of FR mice displayed decreased tip $\Delta \mathrm{L}$ compared with controls (median $\Delta \mathrm{L}_{\text {tips }} \mathrm{L} 5$ : ctrl, $-7.25 \mu \mathrm{m}$; depr, $-2.84 \mu \mathrm{m}$; spared, $-1.96 \mu \mathrm{m} ; p<0.05$, Kruskal-Wallis followed by Dunn's multiple-comparisons test). This indicated that the average increase in tip stabilization after FR was a phenomenon common to the entire cell population and was not caused by reduced retractions of many tips in just one or a few cells.

We next questioned whether those small-scale changes in dendrite tips had affected the gross morphology and organization of pyramidal cell dendritic arbors. To address this we reconstructed and traced individual apical tufts of L2/3 and L 5 cells, as well as basal dendrites of a subset of L2/3 cells at the beginning (day -7 to 0 ) and at the end of the experiment (days 56-84) (Fig. 5 ). For each dendrite we measured total dendrite length, branch number, branch order, and tortuosity and computed the ratio between the last and first time point (Fig. 5F). We included dendrites when the entire arbor was clearly traceable at both time points. Dendrite tufts were excluded from length measurements if one or more tips were not clearly identifiable at either time point. On average in both, control and lesioned animals, dendrites of L2/3 and L5 cells displayed a minor reduction in length (median ratios: L2/3 ctrl, 0.97; L2/3 depr, 0.99; L5 ctrl, 0.92; L5 depr, 0.98). However the ratios were not significantly different from one another (Kruskal-Wallis followed by Dunn's multiplecomparison test; L2/3 $n_{\text {apical }} / n_{\text {basal }}$ : ctrl, 4/3; FR, 3/6; L5 $n_{\text {apical }}$ : ctrl, 5; FR, 10). Dendrite tortuosity, branch number and order (median ratios: L2/3 ctrl, 1.0; L2/3 depr, 1.0; L5 ctrl, 1.0; L5 depr, $1.0)$ remained unaltered after FR (L2/3 $n_{\text {apical }} / n_{\text {basal }}: \mathrm{ctrl}, 4 / 10 ; \mathrm{FR}$, 3/10; L5 $n_{\text {apical }}:$ ctrl, 6; FR, 10). Hence, although individual cells displayed a reduction in dendrite tip length the gross organization and complexity of dendritic trees remained unaltered after FR. Together, the combined IOS and 2PLSM data suggest that, large-scale structural changes in dendrites may not be needed to support nerve deafferentation-mediated expansions of spared whisker representations in mice.

\section{Pyramidal cell dendritic spine dynamics}

Previously it was shown that new spine generation and their subsequent stabilization correlates with cortical map plasticity (Trachtenberg et al., 2002; Holtmaat et al., 2006; Majewska et al., 2006; Keck et al., 2008; Hofer et al., 2009). This work also indicated that spine dynamics differ between pyramidal cell types (Holtmaat et al., 2006; Hofer et al., 2009). To assess the extent with which the observed functional modifications after FR are accompanied by rearrangement of excitatory synaptic connections, we measured spine dynamics on both L2/3 and L5 cells (Fig. 6A-E). Spine densities on L2/3 cells remained unaltered over time and were not affected by FR (Fig. $6 F$ ). Similarly, spine turnover ratios did not differ significantly between the two experimental groups (Fig. 6G), indicating that spine formation and pruning remains balanced after FR. To estimate whether newly formed spines are integrated into the synaptic circuitry we measured the cumulative density of new spines that remained present over a minimum-period of $14 \mathrm{~d}$. New spines that persist for this amount of time (termed new persistent, NP) were previously shown to always bear synapses and are likely to contribute to changes in the synaptic network (Knott et al., 2006). L2/3 cells of deprived barrel columns displayed an increase in both the density 
A
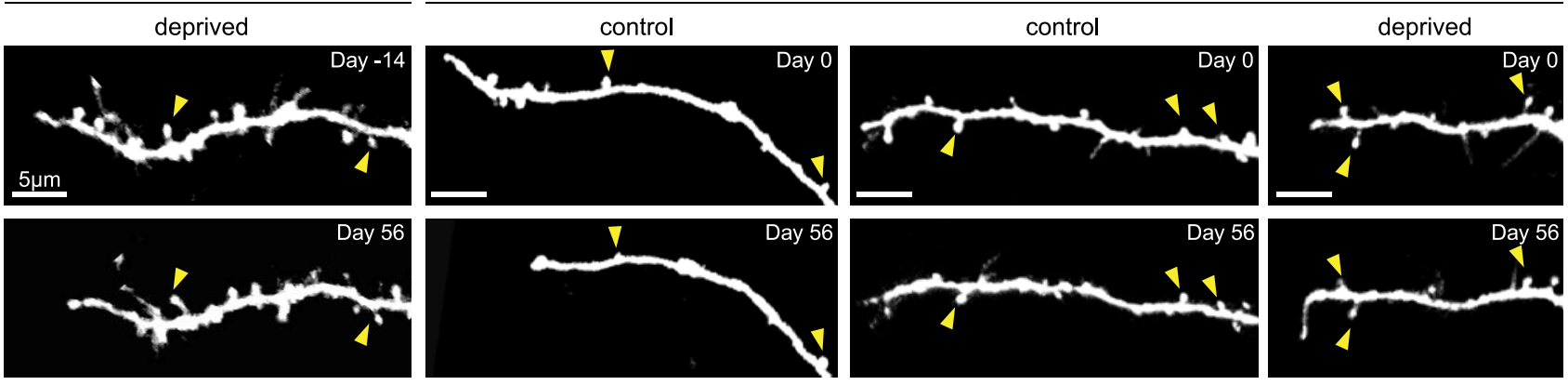

B

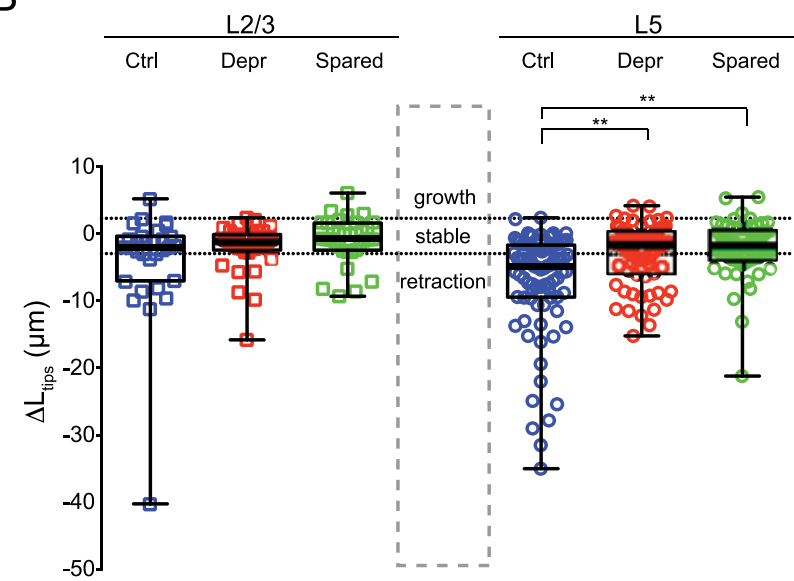

E

L2/3

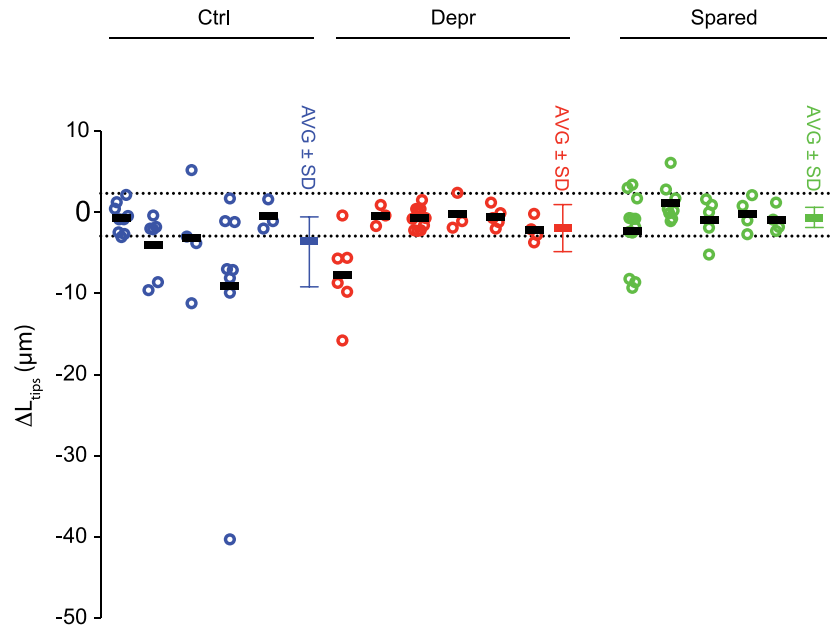

C
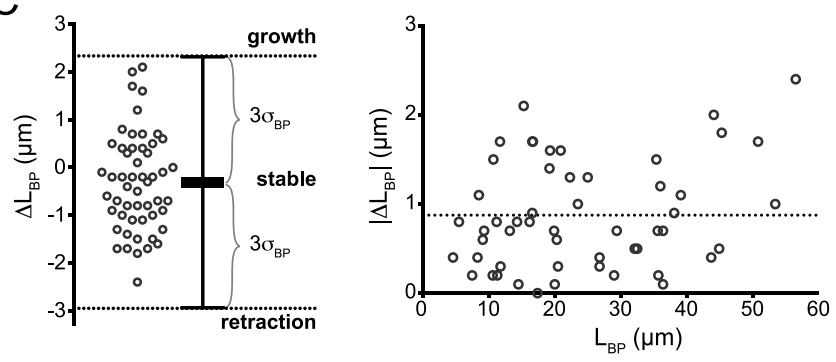

D
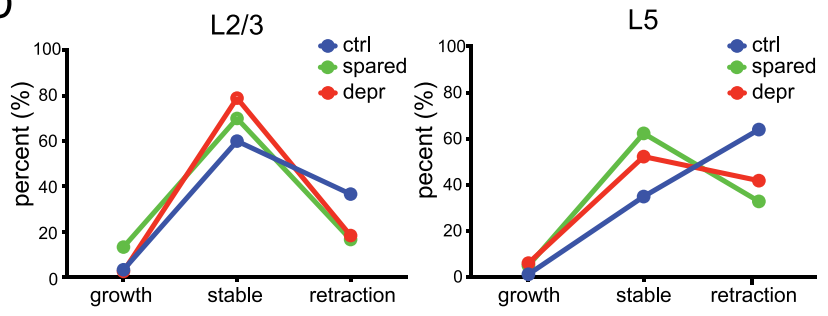

F L5

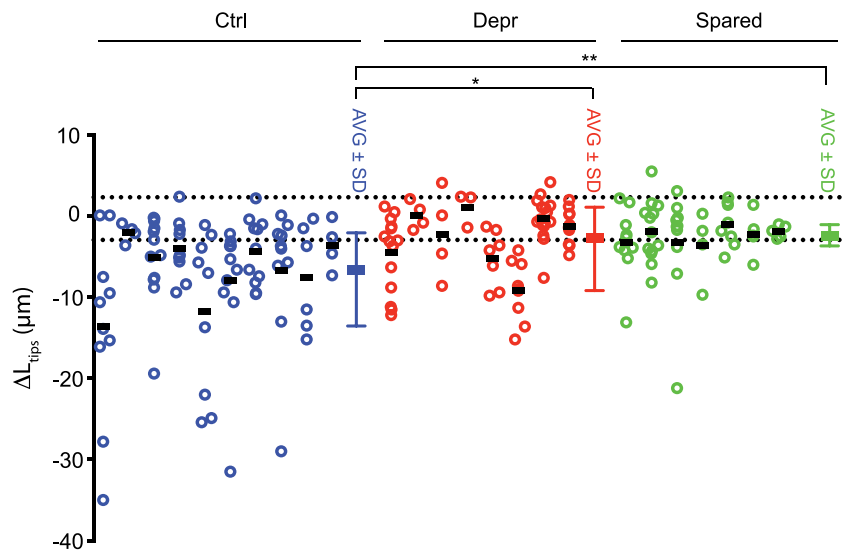

Figure 4. Length changes of individual L2/3 and L 5 cell terminal branches. Terminal branch (tip) length of individual $L 2 / 3$ and $L 5$ cell dendrites was measured at days 0 and 56 of the experiment. $A$, Examples of tips in control and lesioned animals that either displayed a net retraction, stability, or growth over $56 \mathrm{~d}$. Arrowheads point to stable spines, which can be used as fiducial points to compare tips at different time points. Note, the deprived $L 5$ cell tip displayed here belongs to the apical dendrite tuft shown in Figure $5 . \boldsymbol{B}$, Length changes $\left(\Delta \mathrm{L}_{\text {tips }}\right)$ measured for individual tips. FR increases the average $\Delta \mathrm{L}_{\text {tips }}$ in both deprived and spared areas of the barrel cortex. $C$, Left panel: Length change between branch points $\left(\Delta \mathrm{L}_{\mathrm{BP}}\right)$ over a $56 \mathrm{~d}$ interval. Dotted lines indicate the thresholds for significant length changes. Right panel, The absolute length change $\left|\Delta \mathrm{L}_{B P}\right|$ between branch points as a function of the length between branch points $\left(\mathrm{L}_{B P}\right)$. This shows that the noise estimate is not dependent on the distance between branch points (linear fit, $\left.R^{2}=0.069, p=0.057\right)$. Dotted line indicates the SD of $\Delta \mathrm{L}_{\mathrm{BP}}\left(\sigma_{\mathrm{BP}}=0.88 \mu \mathrm{m}\right)$. $D$, Significant length changes displayed as a fraction of the total number of tips analyzed. Note that the tendency of $L 5$ cell dendrites toward retraction is disrupted by FR and shifted toward stability $\left(p<0.01, \chi^{2}\right.$ test). $L 2 / 3$ cell dynamics are not affected by $F R . E, F$, The length changes measured for individual $L 2 / 3$ and $L 5$ cell tips $(\boldsymbol{B})$ that belong to the same cell were pooled together and plotted as groups. AVG, Average $\Delta \mathrm{L}_{\text {tips }}$ across cells. Note: cells of which $<3$ tips were measured were excluded from this analysis. ${ }^{*} p<0.05$; ${ }^{* *} p<0.005$, Kruskal-Wallis followed by Dunn's multiple-comparison test. 
A

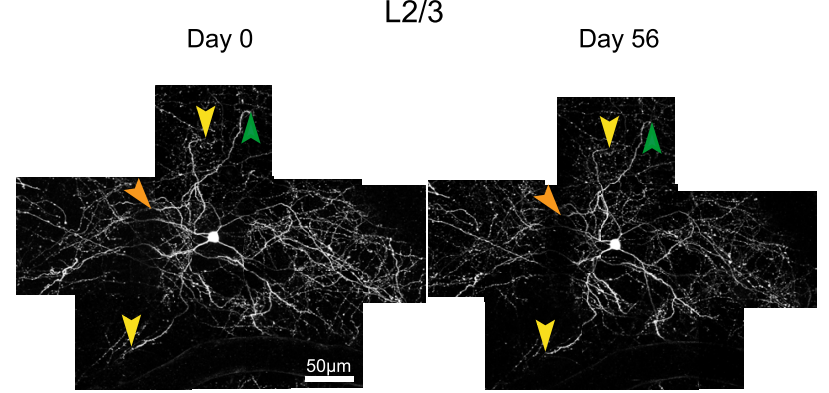

B
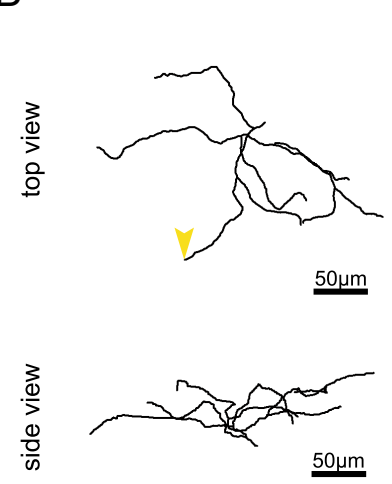

C
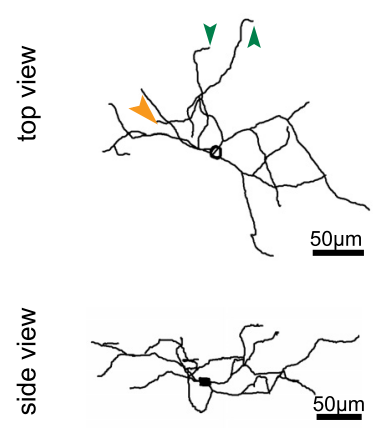

apical
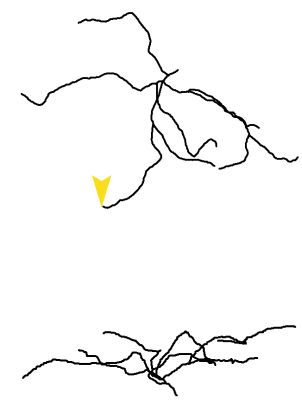

basal
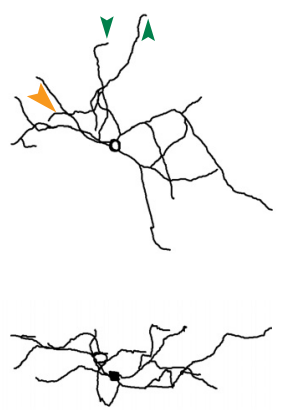

D

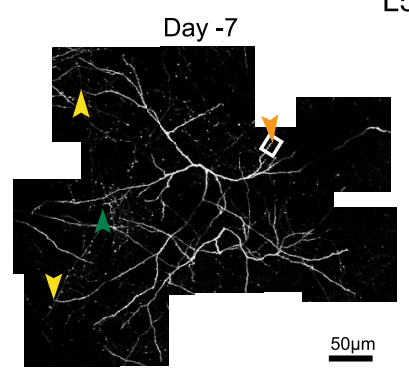

L5

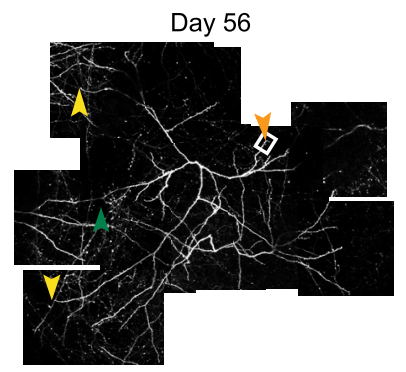

E
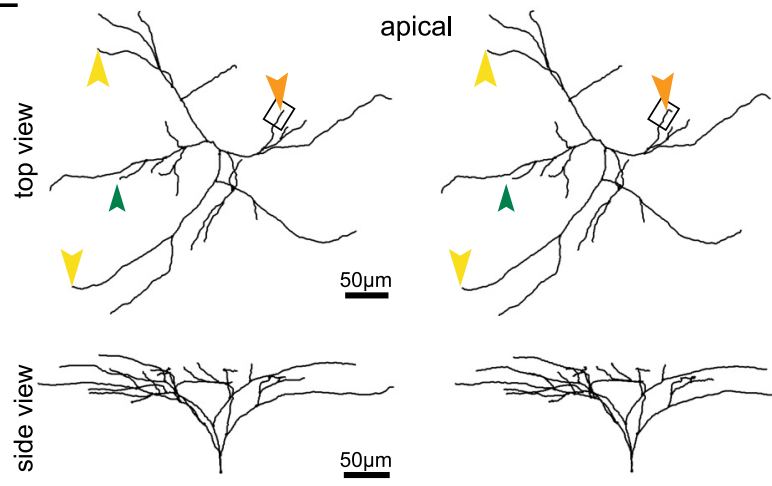

$\mathrm{F}$
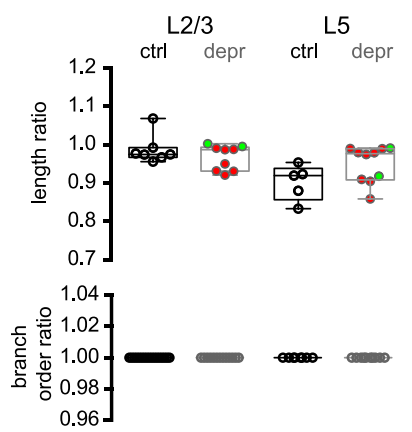
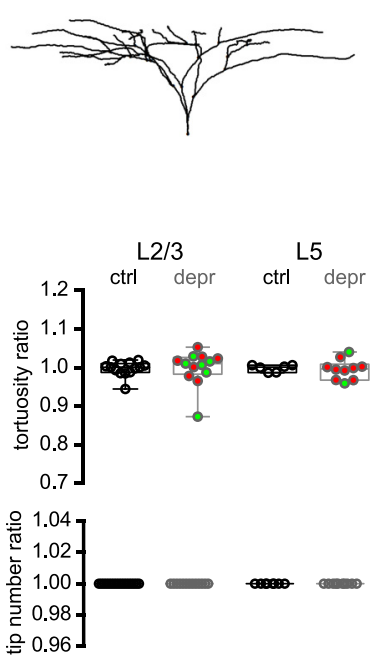

Figure 5. Gross morphology of dendrites remains stable after FR. $A, D, 2 P L S M$ images of $L 2 / 3(\boldsymbol{A})$ and $L 5$ (D) cell apical dendrite tufts at days 0 and 56 . Arrowheads point to stable (yellow), growing (orange), and retracting (green) terminal branches. Boxed region corresponds to the deprived $L 5$ dendrite example displayed in Figure 4. B, C, E, Neurolucida traces of the apical tufts and basal dendrites of the cells in $(\boldsymbol{A})$ and $(\boldsymbol{D})$. $\boldsymbol{F}$, Dendrite complexities per tuft, as ratios (d 56/0) of total length, dendrite tortuosity, number of terminal branches, and branch order. Filled circles represent dendrites of cells in control (black), deprived (red), and spared (green) barrel columns.

and the fraction of NP spines (Fig. 6 H,I). Although some parameters tended toward a difference, we did not detect a significant effect of FR on spine density, turnover ratios (Fig. $6 \mathrm{~J}, \mathrm{~K}$ ), and NP spine formation (Fig. $6 L, M$ ) on L5 cells. This suggests that the complete and long-term removal of a large fraction of barrel cortex inputs precludes synaptic network changes for L5 cells, similar to the reduced L5 spine elimination that was observed after trimming of the entire whisker pad (Zuo et al., 2005) or complete retinal lesions (Keck et al., 2008).

\section{Discussion}

\section{Whisker-map plasticity}

We monitored the reorganization of whisker representations in the mouse barrel cortex and the associated structural changes in pyramidal cell dendrites over several months following FR, a procedure that severs the follicular nerve and causes long-term deafferentation of the trigeminal nuclei (Dorfl, 1985). We found that FR triggered a robust expansion of spared whisker-evoked IOS responses (Figs. 2, 3). Whisker-evoked IOS responses in the so- matosensory cortex have been shown to correlate with spiking activity of cortical networks (Peterson et al., 1998; Polley et al., 1999; Drew and Feldman, 2009). Changes in whisker-evoked IOS responses in the adult rodent barrel cortex have also been detected after whisker plucking or trimming, and are paralleled by changes in whisker-evoked spiking in supragranular layers (Polley et al., 1999; Drew and Feldman, 2009; Margolis et al., 2012). Therefore, the expansion of IOS signals in our study is also likely to represent increased activity of supragranular cortical neurons in response to spared whisker deflections. We found that the IOS responses had significantly expanded along the axis perpendicular to the spared rows, well into the deprived D and E barrel columns (Fig. 3). This suggests that supragranular cells in the deprived barrel columns had become responsive to the spared $\mathrm{C}$ row whiskers. Our findings corroborate the consensus that spared sensory modalities recruit cortical space at the expense of deprived areas upon long-term sensory deprivation or peripheral deafferentation (Kelahan et al., 1981; Merzenich et al., 1983; 

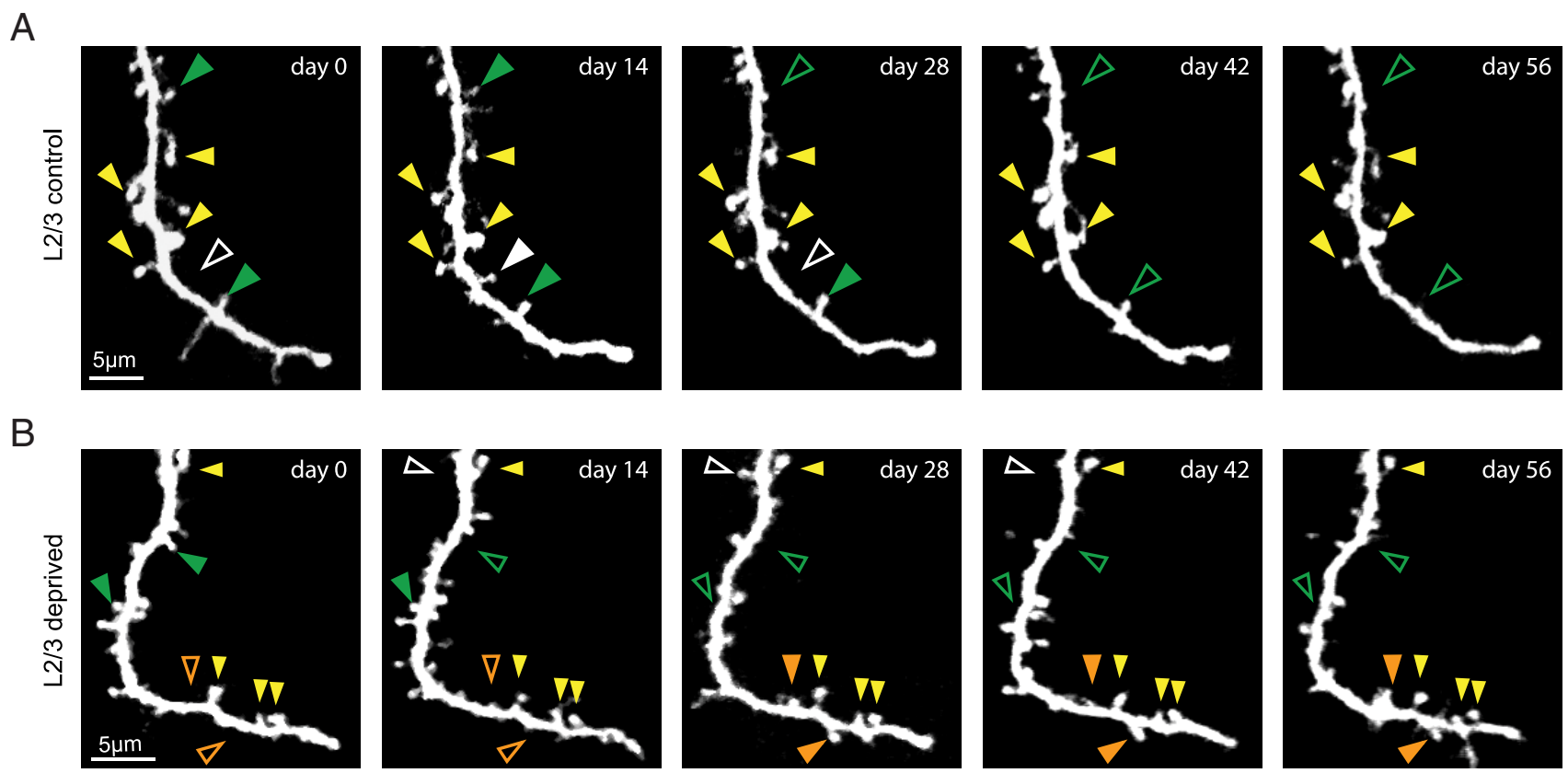

C
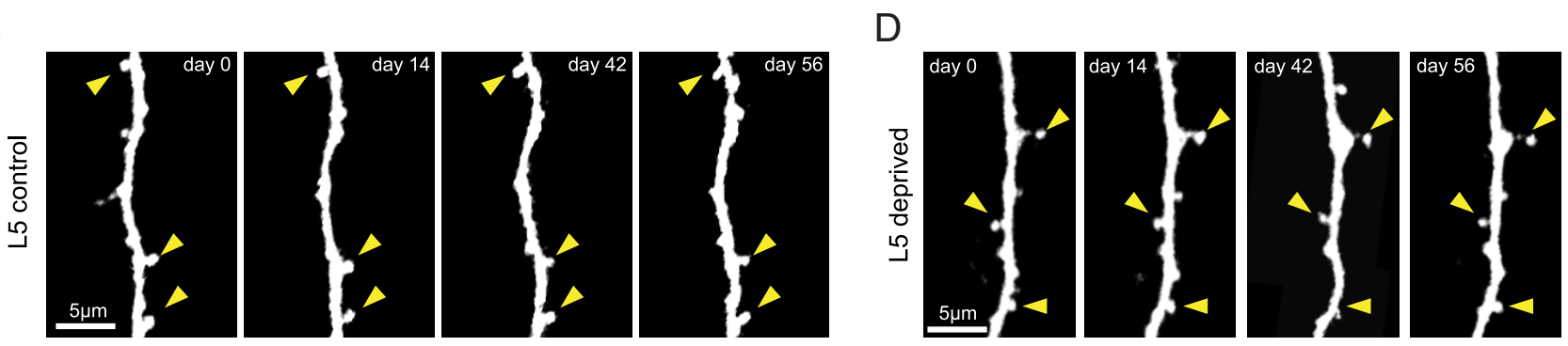

E

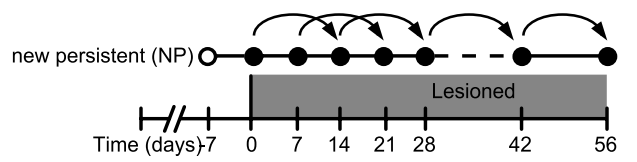

F

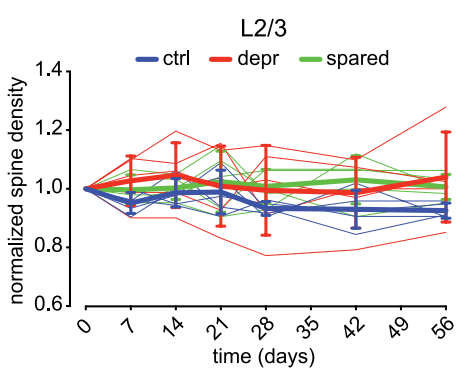

$\checkmark$

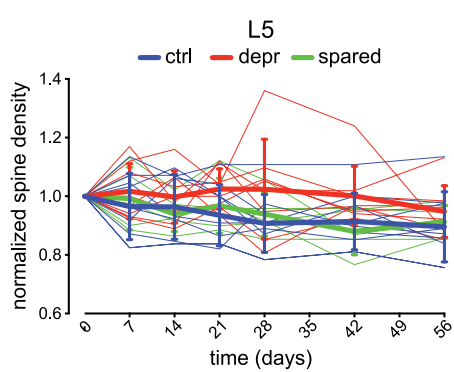

G

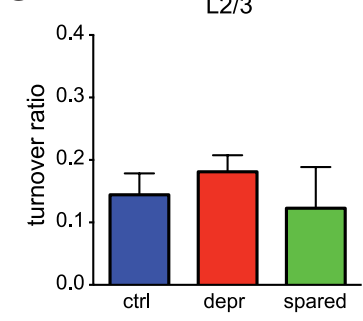

K

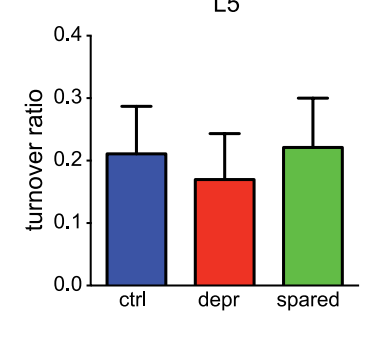

$\mathrm{H}$
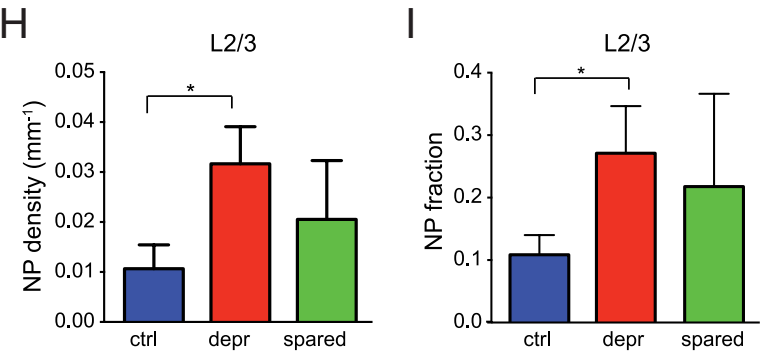

L

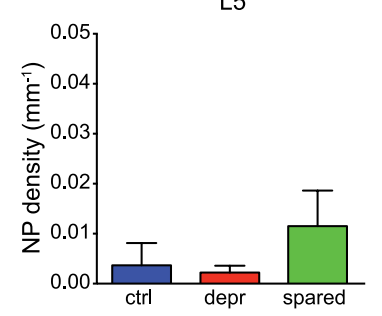

M

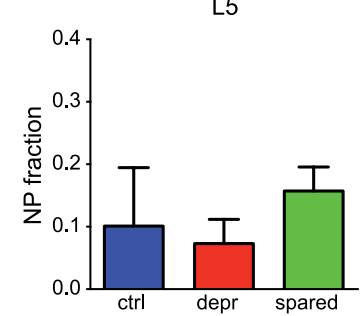

Figure 6. Pyramidal dendritic spine dynamics. $\boldsymbol{A}-\boldsymbol{D}$, High-magnification view of $\mathrm{L} 2 / 3$ cell $(\boldsymbol{A}, \boldsymbol{B})$ and $\mathrm{L} 5$ cell $(\boldsymbol{C}, \boldsymbol{D})$ dendrites imaged at different time points in control $(\boldsymbol{A}, \boldsymbol{C})$ and deprived $(\boldsymbol{B}, \boldsymbol{D})$ barrel columns. Arrowheads:yellow, stable spine; orange, new spine; green, lost spine; white, transient spine. (E) Scoring of NP spines. New spines that survived for a minimum of (Figure legend continues.) 
Manger et al., 1996; Weiss et al., 2000). Interestingly, when IOS responses were measured within the first week after FR, response area expansion was not yet obvious (Fig. 2D), suggesting that the whisker map expansions were based on slow, and perhaps Hebbian types of changes rather than on homeostatic plasticity (e.g., disinhibition) alone (Drew and Feldman, 2009; Feldman, 2009).

\section{Dendrite stability}

We found that L2/3 cell dendrite tip dynamics were unaffected by FR. However FR reduced the dynamics of L5 cell apical dendrite tips. In controls, many L 5 cell tips displayed small net retractions, which on average resulted in a minimal shortening of the apical tufts (Figs. 4, 5). Dendritic shortening has been observed in other studies, and may be a common phenomenon in adult mice (Chow et al., 2009; Allard et al., 2010). We exclude the possibility that this shortening is related to the cranial window preparation. L2/3 cell tips that resided in the same layer as L5 cell apical dendrites, and in some cases were imaged in the same animals, remained highly stable. Our results indicate that reduced sensory input diminishes L5 tip dynamics and facilitates the maintenance of dendritic length. Despite these minor effects on tip dynamics, FR did not affect the large-scale dendrite geometry of both L2/3 and L5 cell dendrites (Fig. 5).

Our findings are in line with the notion that pyramidal dendrites become increasingly stable in the postdevelopmental cortex and usually remain stable under plasticity evoking conditions (Trachtenberg et al., 2002; Maravall et al., 2004; Lee et al., 2006; Mostany and Portera-Cailliau, 2011). Yet they stand in contrast to reports of denervation-induced changes in dendrite orientations (Hickmott and Steen, 2005; Tailby et al., 2005). In those studies the analysis relied on postmortem measurements and group-wise comparisons. Because a longitudinal analysis in vivo is more sensitive, we expected to readily detect orientation changes. However, none of our dendrites showed changes in complexity.

There are several explanations for these differences. First, we studied identified L2/3 and L5 cells, and most of our data were based on apical dendrites located in superficial cortical layers. Tailby et al. (2005) studied basal dendrites of cells positioned in lower layer 3 and layer 4 . The dendrites in our study may have behaved differently from deeper dendrites because the latter receive direct L4 and thalamocortical inputs (Oberlaender et al., 2012a; Feldmeyer et al., 2012). Thalamocortical projections are strong drivers of synaptic input, and have been shown to rearrange upon whisker deprivation, even in the adult somatosensory cortex (Oberlaender et al., 2012b). Plasticity in thalamocortical afferents may efficiently induce parallel structural rearrangements in their postsynaptic inputs. Second, the locations of the cells within the barrel field and the nature of the deprivation differ. Tailby et al. (2005) compared the orientation of dendrites in deprived fields versus undeprived fields. Such comparisons are sensitive to small pre-existing differences between dendrite arborizations in these parts of the barrel field that may be amplified and become significant upon small changes induced by denerva-

\section{$\leftarrow$}

(Figure legend continued.) $14 \mathrm{~d}$ were scored as NP. $\boldsymbol{F}, \boldsymbol{J}$, Normalized L2/3 cell $(\boldsymbol{F})$ and L 5 cell $(\boldsymbol{J})$ spine densities as a function of time. Thin lines, individual cells; thick lines, averages. $\boldsymbol{G}, \boldsymbol{K}$, Turnover of $L 2 / 3$ cell $(G)$ and $L 5$ cell $(K)$ spines between imaging sessions. $\boldsymbol{H}, \boldsymbol{L}$, The cumulative $N$ Pspine density for $L 2 / 3$ cells $(\boldsymbol{H})$ and $L 5$ cells $(\boldsymbol{L}) . \boldsymbol{I}, \boldsymbol{M}$, Cumulative NP fraction: the total number of NP spines as a fraction of the number of spines present on day -7 calculated for $L 2 / 3$ cells $(\boldsymbol{l})$ and L5 cells $(\boldsymbol{M})$. Color code: control, blue; deprived, red; spared, green. ${ }^{*} p<0.05$. tion. Furthermore, map plasticity occurred within rows (e.g., between the $\mathrm{C} 2$ and $\mathrm{C} 3$ barrel), as whisker arcs rather than rows were deafferentated. In our study, the map shifts happened within arcs and across rows (e.g., between the C2 and D2 barrel). Within-row connectivity has been described to be more extensive than the across-row projections (Bernardo et al., 1990a,b; Hoeflinger et al., 1995), and plasticity is more robust along rows than along arcs (Huang et al., 1998).

The differences with the Hickmott and Steen (2005) study are distinct from the points mentioned above. This work focused on cells located between two macroscopic cortical areas (forepaw and lower jaw), whose dendrites naturally have a very strong orientation bias away from the border (Hickmott and Merzenich, 1999). Such strong biases are not typical for apical dendrites in the middle of the barrel field, which often reach into neighboring columns (Holtmaat et al., 2006; Wilbrecht et al., 2010; Hardingham et al., 2011).

\section{Dendritic spine dynamics}

We observed that although dendrites remained stable after FR, a small fraction of spines continued to appear and disappear on L2/3 and L5 cells. Spine density and turnover remained largely unaffected on both cell types. Interestingly, L2/3 pyramidal cells in deprived columns responded to FR with an increased formation of NP spines. On the other hand, NP spine formation on L5 cells was not significantly affected.

The unchanged NP spine formation on L5 cells stands in contrast to observations upon chessboard whisker deprivations (Holtmaat et al., 2006; Wilbrecht et al., 2010), monocular deprivation (Hofer et al., 2009), and small retinal lesions (Keck et al., 2008), where L5 cell dendritic spines reacted strongly to the deprivation. We may have failed to detect an effect due to a lack of sufficient statistical power. However, the differential results could also relate to the severity of deprivation and the size of the cortical area affected in the various studies. Monocular deprivation (Hofer et al., 2009) does not completely silence the excitatory inputs to the binocular visual cortex, because the ipsilateral eye's inputs remain active. Similarly, chessboard whisker deprivations and small retinal lesions result in incomplete silencing of relatively small cortical areas $\left(\sim 0.07 \mathrm{~mm}^{2}\right)$, corresponding to the size of 1-2 barrel columns. Therefore, in those paradigms spine plasticity may be induced by activity of spared competing inputs that innervate the deprived cells. In our study whisker FR presumably silenced a much larger cortical area $\left(\sim 0.6 \mathrm{~mm}^{2}\right.$ to $\sim 0.7$ $\mathrm{mm}^{2}$ ) including competing inputs at the center of the lesion projection zone (Wimmer et al., 2010; Oberlaender et al., 2012b). Therefore, direct sensory-driven activity may have become insufficient to drive spine plasticity on L5 apical dendrites. In fact, the lack of NP spine formation on L5 dendrites in our study shows similarities with results of complete whisker pad trimming (Zuo et al., 2005) or of complete binocular retinal lesions (Keck et al., 2008), in which spine plasticity was reduced.

The increased L2/3 NP spine formation after FR stands in contrast to previous observations in the visual cortex, where L2/3 cell spine dynamics were not affected by transient monocular deprivation (Hofer et al., 2009; Chen et al., 2012; van Versendaal et al., 2012). This dissimilarity may be based on a difference in paradigms. Nevertheless, the spine changes in our study correlate well with the IOS response expansions, which are most likely to reflect granular and supragranular layer plasticity (Brett-Green et al., 2001). NP spines were shown to harbor synapses (Holtmaat et al., 2005; Knott et al., 2006). Thus, L2/3 cells in the deprived part of the barrel cortex may increase their receptive fields and be- 
come responsive to spared neighboring inputs through the formation of new synapse-bearing dendritic spines. In addition, large scale whisker plucking and sensory deafferentation have been shown to elicit axonal sprouting in adults (Yamahachi et al., 2009; Marik et al., 2010). Some individual new horizontally projecting axons originating from the spared cortex may trigger the formation of NP spines specifically on L2/3 cells in the deprived cortex, because they naturally are highly interconnected within superficial layers (Petreanu et al., 2009; Feldmeyer, 2012).

In conclusion, here we describe the effects of long-term whisker sensory deafferentations on dendritic structures and functional whisker representations in the mouse barrel cortex. Spared whisker representations were found to expand into the deprived part of the barrel cortex, a process that was paralleled by and putatively based on the addition of new persistent, synapsebearing spines on L2/3 pyramidal cell dendrites. Surprisingly, the large-scale morphology of L2/3 and L5 dendrites remained unchanged. Together, our data indicate that relatively large functional map shifts in supragranular layers of the cortex do not depend on dendritic growth but are associated with local dendritic spine plasticity.

\section{References}

Accolla R, Bathellier B, Petersen CC, Carleton A (2007) Differential spatial representation of taste modalities in the rat gustatory cortex. J Neurosci 27:1396-1404. CrossRef Medline

Allard S, Scardochio T, Cuello A, Ribeiro-da-Silva A (2010) Correlation of cognitive performance and morphological changes in neocortical pyramidal neurons in aging. Neurobiol Aging 33:1466-1480. CrossRef Medline

Bathellier B, Van De Ville D, Blu T, Unser M, Carleton A (2007) Waveletbased multi-resolution statistics for optical imaging signals: application to automated detection of odour activated glomeruli in the mouse olfactory bulb. Neuroimage 34:1020-1035. CrossRef Medline

Bernardo KL, McCasland JS, Woolsey TA (1990a) Local axonal trajectories in mouse barrel cortex. Exp Brain Res 82:247-253. CrossRef Medline

Bernardo KL, McCasland JS, Woolsey TA, Strominger RN (1990b) Local intra- and interlaminar connections in mouse barrel cortex. J Comp Neurol 291:231-255. CrossRef Medline

Brett-Green BA, Chen-Bee CH, Frostig RD (2001) Comparing the functional representations of central and border whiskers in rat primary somatosensory cortex. J Neurosci 21:9944-9954. Medline

Bruno RM, Hahn TT, Wallace DJ, de Kock CP, Sakmann B (2009) Sensory experience alters specific branches of individual corticocortical axons during development. J Neurosci 29:3172-3181. CrossRef Medline

Chen JL, Villa KL, Cha JW, So PT, Kubota Y, Nedivi E (2012) Clustered dynamics of inhibitory synapses and dendritic spines in the adult neocortex. Neuron 74:361-373. CrossRef Medline

Chklovskii DB, Mel BW, Svoboda K (2004) Cortical rewiring and information storage. Nature 431:782-788. CrossRef Medline

Chow DK, Groszer M, Pribadi M, Machniki M, Carmichael ST, Liu X, Trachtenberg JT (2009) Laminar and compartmental regulation of dendritic growth in mature cortex. Nat Neurosci 12:116-118. CrossRef Medline

Darian-Smith C, Gilbert CD (1994) Axonal sprouting accompanies functional reorganization in adult cat striate cortex. Nature 368:737-740. CrossRef Medline

De Paola V, Holtmaat A, Knott G, Song S, Wilbrecht L, Caroni P, Svoboda K (2006) Cell type-specific structural plasticity of axonal branches and boutons in the adult neocortex. Neuron 49:861-875. CrossRef Medline

Dörfl J (1985) The innervation of the mystacial region of the white mouse: A topographical study. J Anat 142:173-184. Medline

Drew PJ, Feldman DE (2009) Intrinsic signal imaging of deprivationinduced contraction of whisker representations in rat somatosensory cortex. Cereb Cortex 19:331-348. CrossRef Medline

Dubroff JG, Stevens RT, Hitt J, Maier DL, McCasland JS, Hodge CJ (2005) Use-dependent plasticity in barrel cortex: intrinsic signal imaging reveals functional expansion of spared whisker representation into adjacent deprived columns. Somatosens Mot Res 22:25-35. CrossRef Medline
Feldman DE (2009) Synaptic mechanisms for plasticity in neocortex. Annu Rev Neurosci 32:33-55. CrossRef Medline

Feldmeyer D (2012) Excitatory neuronal connectivity in the barrel cortex. Front Neuroanat 6:24. CrossRef Medline

Feldmeyer D, Brecht M, Helmchen F, Petersen CC, Poulet JF, Staiger JF, Luhmann HJ, Schwarz C (2012) Barrel cortex function. Prog Neurobiol 103:3-27. CrossRef Medline

Feng G, Mellor RH, Bernstein M, Keller-Peck C, Nguyen QT, Wallace M, Nerbonne JM, Lichtman JW, Sanes JR (2000) Imaging neuronal subsets in transgenic mice expressing multiple spectral variants of GFP. Neuron 28:41-51. CrossRef Medline

Florence SL, Taub HB, Kaas JH (1998) Large-scale sprouting of cortical connections after peripheral injury in adult macaque monkeys. Science 282 : 1117-1121. CrossRef Medline

Grinvald A, Lieke E, Frostig RD, Gilbert CD, Wiesel TN (1986) Functional architecture of cortex revealed by optical imaging of intrinsic signals. Nature 324:361-364. CrossRef Medline

Hardingham NR, Gould T, Fox K (2011) Anatomical and sensory experiential determinants of synaptic plasticity in layer $2 / 3$ pyramidal neurons of mouse barrel cortex. J Comp Neurol 519:2090-2124. CrossRef Medline

Harris RM, Woolsey TA (1981) Dendritic plasticity in mouse barrel cortex following postnatal vibrissa follicle damage. J Comp Neurol 196:357-376. CrossRef Medline

Hickmott PW, Steen PA (2005) Large-scale changes in dendritic structure during reorganization of adult somatosensory cortex. Nat Neurosci 8:140-142. CrossRef Medline

Hickmott PW, Ethell IM (2006) Dendritic plasticity in the adult neocortex. Neuroscientist 12:16-28. CrossRef Medline

Hickmott PW, Merzenich MM (1999) Dendritic bias of neurons in rat somatosensory cortex associated with a functional boundary. J Comp Neurol 409:385-399. CrossRef Medline

Hoeflinger BF, Bennett-Clarke CA, Chiaia NL, Killackey HP, Rhoades RW (1995) Patterning of local intracortical projections within the vibrissae representation of rat primary somatosensory cortex. J Comp Neurol 354: 551-563. CrossRef Medline

Hofer SB, Mrsic-Flogel TD, Bonhoeffer T, Hübener M (2009) Experience leaves a lasting structural trace in cortical circuits. Nature 457:313-317. CrossRef Medline

Holtmaat A, Svoboda K (2009) Experience-dependent structural synaptic plasticity in the mammalian brain. Nat Rev Neurosci 10:647-658. CrossRef Medline

Holtmaat AJ, Trachtenberg JT, Wilbrecht L, Shepherd GM, Zhang X, Knott GW, Svoboda K (2005) Transient and persistent dendritic spines in the neocortex in vivo. Neuron 45:279-291. CrossRef Medline

Holtmaat A, Wilbrecht L, Knott GW, Welker E, Svoboda K (2006) Experience-dependent and cell-type-specific spine growth in the neocortex. Nature 441:979-983. CrossRef Medline

Holtmaat A, Bonhoeffer T, Chow DK, Chuckowree J, De Paola V, Hofer SB, Hübener M, Keck T, Knott G, Lee WC, Mostany R, Mrsic-Flogel TD, Nedivi E, Portera-Cailliau C, Svoboda K, Trachtenberg JT, Wilbrecht L (2009) Long-term, high-resolution imaging in the mouse neocortex through a chronic cranial window. Nat Protoc 4:1128-1144. CrossRef Medline

Huang W, Armstrong-James M, Rema V, Diamond ME, Ebner FF (1998) Contribution of supragranular layers to sensory processing and plasticity in adult rat barrel cortex. J Neurophysiol 80:3261-3271. Medline

Keck T, Mrsic-Flogel TD, Vaz Afonso M, Eysel UT, Bonhoeffer T, Hübener M (2008) Massive restructuring of neuronal circuits during functional reorganization of adult visual cortex. Nat Neurosci 11:1162-1167. CrossRef Medline

Kelahan AM, Ray RH, Carson LV, Massey CE, Doetsch GS (1981) Functional reorganization of adult raccoon somatosensory cerebral cortex following neonatal digit amputation. Brain Res 223:152-159. CrossRef Medline

Kinoshita M, Gilbert CD, Das A (2009) Optical imaging of contextual interactions in V1 of the behaving monkey. J Neurophysiol 102:1930-1944. CrossRef Medline

Knott GW, Holtmaat A, Wilbrecht L, Welker E, Svoboda K (2006) Spine growth precedes synapse formation in the adult neocortex in vivo. Nat Neurosci 9:1117-1124. CrossRef Medline

Kossut M, Juliano SL (1999) Anatomical correlates of representational map 
reorganization induced by partial vibrissectomy in the barrel cortex of adult mice. Neuroscience 92:807-817. CrossRef Medline

Lee WC, Huang H, Feng G, Sanes JR, Brown EN, So PT, Nedivi E (2006) Dynamic remodeling of dendritic arbors in GABAergic interneurons of adult visual cortex. PLoS Biol 4:e29. CrossRef Medline

Lendvai B, Stern EA, Chen B, Svoboda K (2000) Experience-dependent plasticity of dendritic spines in the developing rat barrel cortex in vivo. Nature 404:876-881. CrossRef Medline

Madisen L, Zwingman TA, Sunkin SM, Oh SW, Zariwala HA, Gu H, Ng LL, Palmiter RD, Hawrylycz MJ, Jones AR, Lein ES, Zeng H (2010) A robust and high-throughput Cre reporting and characterization system for the whole mouse brain. Nat Neurosci 13:133-140. CrossRef Medline

Majewska A, Sur M (2003) Motility of dendritic spines in visual cortex in vivo: changes during the critical period and effects of visual deprivation. Proc Natl Acad Sci U S A 100:16024-16029. CrossRef Medline

Majewska AK, Newton JR, Sur M (2006) Remodeling of synaptic structure in sensory cortical areas in vivo. J Neurosci 26:3021-3029. CrossRef Medline

Manger PR, Woods TM, Jones EG (1996) Plasticity of the somatosensory cortical map in macaque monkeys after chronic partial amputation of a digit. Proc Biol Sci 263:933-939. CrossRef Medline

Maravall M, Koh IY, Lindquist WB, Svoboda K (2004) Experiencedependent changes in basal dendritic branching of layer $2 / 3$ pyramidal neurons during a critical period for developmental plasticity in rat barrel cortex. Cereb Cortex 14:655-664. CrossRef Medline

Margolis DJ, Lütcke H, Schulz K, Haiss F, Weber B, Kügler S, Hasan MT, Helmchen F (2012) Reorganization of cortical population activity imaged throughout long-term sensory deprivation. Nat Neurosci 15: 1539-1546. CrossRef Medline

Marik SA, Yamahachi H, McManus JN, Szabo G, Gilbert CD (2010) Axonal dynamics of excitatory and inhibitory neurons in somatosensory cortex. PLoS Biol 8:e1000395. CrossRef Medline

Merzenich MM, Kaas JH, Wall J, Nelson RJ, Sur M, Felleman D (1983) Topographic reorganization of somatosensory cortical areas $3 \mathrm{~b}$ and 1 in adult monkeys following restricted deafferentation. Neuroscience 8:33-55. CrossRef Medline

Mostany R, Portera-Cailliau C (2011) Absence of large-scale dendritic plasticity of layer 5 pyramidal neurons in peri-infarct cortex. J Neurosci 31 : 1734-1738. CrossRef Medline

Navarro X, Viv ó M, Valero-Cabr é A (2007) Neural plasticity after peripheral nerve injury and regeneration. Prog Neurobiol 82:163-201. CrossRef Medline

Oberlaender M, de Kock CP, Bruno RM, Ramirez A, Meyer HS, Dercksen VJ, Helmstaedter M, Sakmann B (2012a) Cell type-specific threedimensional structure of thalamocortical circuits in a column of rat vibrissal cortex. Cereb Cortex 22:2375-2391. CrossRef Medline

Oberlaender M, Ramirez A, Bruno RM (2012b) Sensory experience restruc- tures thalamocortical axons during adulthood. Neuron 74:648-655. CrossRef Medline

Peterson BE, Goldreich D, Merzenich MM (1998) Optical imaging and electrophysiology of rat barrel cortex:I. Responses to small single-vibrissa deflections. Cereb Cortex 8:173-183. CrossRef Medline

Petreanu L, Mao T, Sternson SM, Svoboda K (2009) The subcellular organization of neocortical excitatory connections. Nature 457:1142-1145. CrossRef Medline

Polley DB, Chen-Bee CH, Frostig RD (1999) Two directions of plasticity in the sensory-deprived adult cortex. Neuron 24:623-637. CrossRef Medline

Pologruto TA, Sabatini BL, Svoboda K (2003) ScanImage: flexible software for operating laser scanning microscopes. Biomed Eng Online 2:13. CrossRef Medline

Portera-Cailliau C, Weimer RM, De Paola V, Caroni P, Svoboda K (2005) Diverse modes of axon elaboration in the developing neocortex. PLoS Biol 3:e272. CrossRef Medline

Reimold M, Slifstein M, Heinz A, Mueller-Schauenburg W, Bares R (2006) Effect of spatial smoothing on $t$-maps: arguments for going back from $t$-maps to masked contrast images. J Cereb Blood Flow Metab 26:751-759. CrossRef Medline

Rosenfeld A, Kak AC, Kak AC (1982) Digital picture processing, vol 1, Ed 2 (computer science and applied mathematics). New York: Academic.

Tailby C, Wright LL, Metha AB, Calford MB (2005) Activity-dependent maintenance and growth of dendrites in adult cortex. Proc Natl Acad Sci U S A 102:4631-4636. CrossRef Medline

Trachtenberg JT, Chen BE, Knott GW, Feng G, Sanes JR, Welker E, Svoboda $\mathrm{K}$ (2002) Long-term in vivo imaging of experience-dependent synaptic plasticity in adult cortex. Nature 420:788-794. CrossRef Medline

van Versendaal D, Rajendran R, Saiepour MH, Klooster J, Smit-Rigter L, Sommeijer JP, De Zeeuw CI, Hofer SB, Heimel JA, Levelt CN (2012) Elimination of inhibitory synapses is a major component of adult ocular dominance plasticity. Neuron 74:374-383. CrossRef Medline

Weiss T, Miltner WH, Huonker R, Friedel R, Schmidt I, Taub E (2000) Rapid functional plasticity of the somatosensory cortex after finger amputation. Exp Brain Res 134:199-203. CrossRef Medline

Wilbrecht L, Holtmaat A, Wright N, Fox K, Svoboda K (2010) Structural plasticity underlies experience-dependent functional plasticity of cortical circuits. J Neurosci 30:4927-4932. CrossRef Medline

Wimmer VC, Broser PJ, Kuner T, Bruno RM (2010) Experience-induced plasticity of thalamocortical axons in both juveniles and adults. J Comp Neurol 518:4629-4648. CrossRef Medline

Yamahachi H, Marik SA, McManus JN, Denk W, Gilbert CD (2009) Rapid axonal sprouting and pruning accompany functional reorganization in primary visual cortex. Neuron 64:719-729. CrossRef Medline

Zuo Y, Yang G, Kwon E, Gan WB (2005) Long-term sensory deprivation prevents dendritic spine loss in primary somatosensory cortex. Nature 436:261-265. CrossRef Medline 